\title{
New insights into Mesozoic cycad evolution: an exploration of anatomically preserved Cycadaceae seeds from the Jurassic Oxford Clay biota
}

\author{
Alan RT Spencer \\ Russell J Garwood \\ Andrew R Rees ${ }^{4}$, Robert J Raine \\ TJ Hollingworth ${ }^{4,8}$, Jason Hilton ${ }^{4,9}$ \\ 1 Department of Earth Science and Engineering, Imperial College London, London, United Kingdom \\ 3 Department of Earth Sciences, The Natural History Museum London, London, United Kingdom \\ 4 School of Geography, Earth and Environmental Sciences, University of Birmingham, Birmingham, United Kingdom \\ 5 Geological Survey of Northern Ireland, Belfast, United Kingdom \\ 6 Department of Botany and Plant Pathology, Oregon State University, Corvallis, Oregon, United States \\ 7 Department of Environmental and Plant Biology, Ohio University, Athens, Ohio, United States \\ 8 Science and Technology Facilities Council, Swindon, United Kingdom \\ 9 Birmingham Institute of Forest Research, University of Birmingham, Birmingham, United Kingdom \\ Corresponding Author: Alan RT Spencer \\ Email address: alan.spencer@imperial.ac.uk
}

Gar W Rothwell

Neville

Most knowledge concerning Mesozoic Era floras has come from compression fossils. This has been augmented in the last 20 years by rarer permineralized material showing cellular preservation. Here we describe a new genus of anatomically preserved gymnosperm seed from the Callovian-Oxfordian (Jurassic) Oxford Clay Formation (UK), using a combination of traditional sectioning and synchrotron radiation X-ray micro-tomography (SRXMT). Oxfordiana motturii gen. et sp. nov. is large and bilaterally symmetrical. It has prominent external ribs, and has a three-layered integument comprising: a narrow outer layer of thick walled cells; a thick middle parenchymatous layer; and innermost a thin fleshy layer. The integument has a longitudinal interior groove and micropyle, enveloping a nucellus with a small pollen chamber. The large size, bilateral symmetry and integumentary groove demonstrate an affinity for the new species within the cycads. Moreover, the internal groove in extant taxa is an autapomorphy of the genus Cycas, where it facilitates seed germination. Based upon the unique seed germination mechanism shared with living species of the Cycadaceae, we conclude that 0 . motturii is a member of the stem-group lineage leading to Cycas after the Jurassic divergence of the Cycadaceae from other extant cycads. SRXMT - for the first time successfully applied to fossils already prepared as slides - reveals the distribution of different mineral phases within the fossil, and allows us to evaluate the taphonomy of Oxfordiana. An early pyrite phase replicates the external surfaces of individual cells, a later carbonate component infilling void spaces. The resulting 
taphonomic model suggests that the relatively small size of the fossils was key to their exceptional preservation, concentrating sulphate-reducing bacteria in a locally closed microenvironment and thus facilitating soft-tissue permineralization. 
1 New insights into Mesozoic cycad

2 evolution: an exploration of anatomically

s preserved Cycadaceae seeds from the

${ }_{4}$ Jurassic Oxford Clay biota

5

6 Alan R. T. Spencer ${ }^{1 *}$, Russell J. Garwood ${ }^{2,3}$, Andrew R. Rees ${ }^{4}$, Robert J. Raine ${ }^{5}$, Gar W. Rothwell ${ }^{6,7}$, Neville

7 T. J. Hollingworth ${ }^{9,4}$, and Jason Hilton ${ }^{4,8}$

9 1. Department of Earth Science \& Engineering, Imperial College London, UK.

10 2. School of Earth and Environmental Sciences, University of Manchester, Manchester, M13 9PL, UK.

11 3. Department of Earth Sciences, The Natural History Museum, Cromwell Road, London SW7 5BD, UK.

12 4. School of Geography, Earth and Environmental Sciences, University of Birmingham, Edgbaston, Birmingham, B15 2TT, UK.

13 5. Geological Survey of Northern Ireland, Dundonald House, Upper Newtownards Road, Ballymiscaw, Belfast, BT4 3SB, UK

14 6. Department of Botany and Plant Pathology, Oregon State University, Corvallis, OR 97331-2902, USA.

157 7. Department of Environmental and Plant Biology, Ohio University, Athens, OH 45701, USA.

16 8. Birmingham Institute of Forest Research, University of Birmingham, Edgbaston, Birmingham, B15 2TT, UK.

17 9. Science and Technology Facilities Council, Swindon, SN2 1SZ, UK

18 *Author for correspondence.

\section{Abstract}

Most knowledge concerning Mesozoic Era floras has come from compression fossils. This has been augmented in the last 20 years by rarer permineralized material showing cellular preservation. Here we describe a new genus of anatomically preserved gymnosperm seed from the Callovian-Oxfordian (Jurassic) Oxford Clay Formation (UK), using a combination of traditional sectioning and synchrotron 


\section{Introduction} permineralization.

radiation X-ray micro-tomography (SRXMT). Oxfordiana motturii gen. et sp. nov. is large and bilaterally symmetrical. It has prominent external ribs, and has a three-layered integument comprising: a narrow outer layer of thick walled cells; a thick middle parenchymatous layer; and innermost a thin fleshy layer. The integument has a longitudinal interior groove and micropyle, enveloping a nucellus with a small pollen chamber. The large size, bilateral symmetry and integumentary groove demonstrate an affinity for the new species within the cycads. Moreover, the internal groove in extant taxa is an autapomorphy of the genus Cycas, where it facilitates seed germination. Based upon the unique seed germination mechanism shared with living species of the Cycadaceae, we conclude that $O$. motturii is a member of the stem-group lineage leading to Cycas after the Jurassic divergence of the Cycadaceae from other extant cycads. SRXMT — for the first time successfully applied to fossils already prepared as slides reveals the distribution of different mineral phases within the fossil, and allows us to evaluate the taphonomy of Oxfordiana. An early pyrite phase replicates the external surfaces of individual cells, a later carbonate component infilling void spaces. The resulting taphonomic model suggests that the relatively small size of the fossils was key to their exceptional preservation, concentrating sulphatereducing bacteria in a locally closed microenvironment and thus facilitating soft-tissue

Our present understanding of Jurassic vegetation is built largely upon the compression/impression fossil record. This provides important insights into plant morphology and diversity, as well as the temporal and spatial distributions of plants during the Mesozoic Era (Taylor, Taylor \& Krings, 2009). This form of preservation is comparatively common in the geological record, and can include cellular details from cuticles that can be both informative systematically (Stockey, 1994) and environmentally (e.g. Barbacka 
\& van Konijnenburg-van Cittert, 1998). Less common in the Mesozoic Era fossil record, however, is anatomical preservation in which plant cells and tissues are preserved in high fidelity, with permineralized fossil providing key insights into plant ontogeny, physiology, systematic affinities, and phylogenetic relationships that are not possible through other modes of preservation. Although the Jurassic flora of Britain is comparatively well-known from compression/impression assemblages and cuticles (van Konijnenburg-van Cittert \& Morgans, 1999; Cleal et al., 2001; van Konijnenburg-van Cittert, 2008), only five British sites with anatomical preservation of Jurassic plant reproductive organs have been recognized previously (Fig. 1) amongst more frequent accounts of permineralized wood (e.g. Cleal et al., 2001; van Konijnenburg-van Cittert, 2008). The most important of these is the Aalenian StageBajocian Stage Bearreraig Sandstone Fm at Bearreraig Bay on the Isle of Skye (Bateman \& Morton, 1994; Bateman, Morton \& Dower, 2000; Cleal et al., 2001; Dower, Bateman \& Stevenson, 2004; Spencer et al., 2015 ) in which marine carbonate concretions preserve a range of vegetative and fertile organs produced by ferns, cycads and conifers. The same mode of preservation is found in the Kimmeridgian Kimmeridge Clay Fm at Eathie (Cleal et al., 2001), which contains exceptionally well preserved conifer cones (Seward \& Bancroft, 1913; Rothwell et al., 2011; Rothwell et al., 2012; Rothwell et al., 2013) and Bennettitales (Seward, 1913). At Runswick Bay on the Yorkshire coast, Aalenian Stage in age, anatomically preserved plants - cycad leaves and cones and also cones of Bennettiales - occur in siderite concretions (Cleal et al., 2001). Other British Jurassic sites with permineralization preserve a single kind of plant organ. For example, carbonate-preserved pollen cones of cheirolepidiacean conifers are found in the Callovian Stage Kellaways Sand Mbr near Cirencester (Rothwell et al., 2007), and silicified ovulate cones of Cheirolepidiaceae from the Tithonian Purbeck Gp at Chicksgrove (Steart et al., 2014). Each of these assemblages is unusual because it preserves terrestrial plants in marine depositional environments where permineralization occurred rapidly after transport and deposition to prevent significant decay (Wignall \& Pickering, 1993; Bateman, Morton \& Dower, 2000). 
Here we describe the first anatomically preserved plant fossils from the Oxfordian Stage (late Middle Jurassic) Oxford Clay Fm of England (Fig. 2A). The fossils have been studied using a combination of traditional semi-destructive sectioning techniques (Spencer, Hilton \& Sutton, 2013), X-ray microtomography (Spencer et al., 2015) and X-ray synchrotron microtomography (Steart et al., 2014).

Through the recovery of excellent anatomical information from a few high-quality specimens, we establish a new genus and species of gymnosperm ovule Oxfordiana motturii ART Spencer \& J Hilton gen. et sp. nov. Furthermore, because the ovules are preserved in pyrite and carbonate, which are readily differentiated using SRXMT, we report in detail the taphonomy of fossil plants representative of those permineralized in marine depositional settings.

\section{Material and methods}

Two anatomically preserved specimens were collected from the Oxford Clay Fm at different sites. We consider these to be the same species due to consistent morphology and anatomical arrangement.

Specimen BU 5265 was collected from Marston Maisey, near Cirencester (Fig. 2B; 51.667 N, -1.806 W;

OS Grid Ref: SU 135 965) in 2011 by J. Motture, and specimen BU 5266 was collected from Dix Pit at residual clay matrix attached to the outer surfaces. Both specimens are deposited at the Lapworth Museum of Geology, University of Birmingham.

The electronic version of this article in Portable Document Format (PDF) will represent a published work according to the International Code of Nomenclature for algae, fungi, and plants (ICN), and hence the 
95

96

97

98

100

101

102

103

104

105

106

107

108

109

110

111

112

113

114

115

116

117

118

new names contained in the electronic version are effectively published under that Code from the electronic edition alone. In addition, new names contained in this work which have been issued with identifiers by IPNI will eventually be made available to the Global Names Index. The IPNI LSIDs can be resolved and the associated information viewed through any standard web browser by appending the LSID contained in this publication to the prefix "http://ipni.org/". The online version of this work is archived and available from the following digital repositories: PeerJ, PubMed Central, and CLOCKSS.

\section{Specimen BU 5265:}

The specimen has a black coalified outer surface with visible pyrite. It was initially photographed (Fig. 3) but later, due to pyrite decay, fragmented before further preparation occurred. The four largest pieces (numbered consecutively BU 5265.1-4) were subsequently mounted on metal stubs for analysis using scanning electron microscopy (SEM). SEM analyses proved inconclusive, so BU 5265.1 and BU 5265.2 were scanned using laboratory-based X-ray microtomography (XMT) on a Nikon Metrology X-Tek HMKST 225 scanner at the Natural History Museum (London, UK). Each fragment was scanned separately using a tungsten reflection target at $180-185 \mathrm{kV}$ and $120 \mu \mathrm{A}$ with a $0.25 \mathrm{~mm}$ copper filter, 0.354 second exposure time for 3142 projections. The resulting 2000 slice tomographic datasets (Datasets S1, S2) had a voxel size of $16 \mu \mathrm{m}$ and were visualized separately using previously described techniques (Spencer, Hilton \& Sutton, 2013). Through the SPIERS software suite (http://spiers-software.org/; Sutton et al., 2012) we created three-dimensional isosurface-based false-colour models (Models S1, S2; Videos S1, S2). The XMT results lacked fine detail, so the specimen was subsequently investigated with SRXMT on the I12 JEEP beamline at the Diamond Light Source (Oxfordshire, UK). The specimens were individually scanned using: a $53 \mathrm{keV}$ incident beam; the 'Module 2' optics, obtaining a 1.8x magnification; and with 1800 projections collected using a PCO.4000 camera with an exposure of 0.45 second. The resulting tomographic datasets, consisting of 2672 individual slices, have a voxel size of $5 \mu \mathrm{m}$ (Video S3; Datasets S3-S5). The individual slice image data were multiplied, enhanced for brightness and contrast, and 
119

120

121

122

123

124

125

126

127

128

129

130

131

132

133

134

despeckled using ImageJ (Abràmoff, Magalhães \& Ram, 2004). Volume rendering of the SRXMT datasets using the open-source volume renderer Drishti (http://sf.anu.edu.au/Vizlab/drishti/; Limaye, 2012) produced false-coloured three-dimensional models that were visualized separately using previously described techniques (Hickman-Lewis et al., 2016); from which high-resolution images and virtual thinsections were created (i.e. Fig. S1 A-E).

\section{Specimen BU 5266:}

The specimen was photographed and measured, during which, however, the exterior surface started to crumble due to extensive pyrite decay (Fig. 4). To stabilize the specimen, it was embedded in low viscosity resin (Buhler Epo-Thin ${ }^{\circledR}$ ) under vacuum, drawing resin into the fossil and excluding contact between air and pyrite. After curing for 24 hours, samples were re-embedded in blocks of epoxy resin, allowing them to be orientated and mounted for precision cutting to reveal anatomical information. This used a low-speed Buhler Isomet wafering saw with a $0.1 \mathrm{~mm}$ wide diamond edged cutting blade as outlined by Hass and Rowe (1999).

The specimen was initially halved longitudinally near to the middle of the ovule. One half was then prepared in longitudinal section and the other in transverse section. Cut surfaces were prepared using the acetate peel technique (Galtier \& Phillips, 1999) through 10 seconds grinding with 400 carborundum to prepare the surfaces, and $5 \% \mathrm{HCL}$ to etch the carbonate for $30-40$ seconds. Peels were mounted using Eukitt. After surfaces were peeled, the specimen was further sectioned to reveal longitudinal/radial and transverse planes, two peels being created from each cut surface. Finally, each block was ground and mounted on glass slides for microscope observation using reflected incident light. The position of peels and wafered sections are shown in Fig. 5. 
143 Selected slide mounted wafers were then studied using the I12 JEEP beamline at the Diamond Light

144 Source (a technology that was unavailable when the specimen was sectioned). All slides were scanned 145 by collecting 1800 projections using 'Module 2' optics: BU 5266.37, BU 5266.38, BU 5266.39 at $70 \mathrm{keV}$

146 with an exposure of 0.5 second, and BU 5266.1, BU 5266.3, and BU 5266.30 at $53 \mathrm{keV}$ with an exposure 147 of 0.45 second. The resulting 2672 slice tomographic datasets have a voxel size of $5 \mu \mathrm{m}$ (Datasets S6148 S10). We visualized data using Drishti to produce greyscale three-dimensional models from which high149 resolution images and virtual thin-sections were created (e.g. S1 F-J). We note that the high brightness 150 of the X-ray beam caused dark brown discolouration of the glass slides.

Figures and videos:

153 Images were processed (cropped, rotated, edge enhanced and equalized for hue and brightness) in 154 GIMP 2, ImageJ (Abràmoff, Magalhães \& Ram, 2004) and Corel ${ }^{\circledR}$ Paint Shop Pro ${ }^{\circledR}$ Photo X2. Figures were constructed in CoralDraw ${ }^{\circledR}$ X7 and Inkscape. Blender ${ }^{\mathrm{TM}}$ (Garwood \& Dunlop, 2014) was used to raytrace images from the 3D models for both figures and video animations. The latter were edited within

157 Blender ${ }^{\mathrm{TM}}$ (Videos S1-S3).

\section{Geological information}

160

161

162

163

164 165
Both specimens were found in the Oxford Clay Fm (Martill \& Hudson, 1991): a 17 m-thick primarily argillaceous unit with a diverse and distinctive macrofauna (Martill \& Hudson, 1991). Specimen BU 5265 was found in a silty blue grey clay lens. In association were thin shell beds co-occurring with the ammonites Creniceras sp. (Munier-Chalmas), Taramelliceras sp. (Campana) and Quenstedtoceras mariae (d'Orbigny). The last of these species defines the earliest Oxfordian Stage Q. mariae Biozone, found at the base of the Weymouth Mbr of the Oxford Clay Fm (Fig. 2A). Ammonites associated with Dix Pit 
specimen BU 5266 include Distichoceras bicostatum (Stahl), Kosmoceras spinosum (Sowerby),

167 Alligaticeras sp. and Quenstedtoceras lamberti (Sowerby). The latter - present in large numbers - is

168 diagnostic of the Q. lamberti ammonite subzone of the Q. lamberti Zone (Martill \& Hudson, 1991).

169 Furthermore, this ovule was collected a few metres below the Lamberti Limestone that represents the

170 top of the Stewartby Mbr (Fig. 2A) of the Oxford Clay Fm, placing this in the latest Callovian Stage.

171 Hence, ammonite biostratigraphy places both the fossils spanning the boundary of the Callovian Stage

172 (Middle Jurassic) and Oxfordian Stage (Upper Jurassic), at about $163.5 \mathrm{Ma}$ (Fig. 2A).

174 The micro- and macrofauna, coupled with the sedimentology of the Oxford Clay Fm, demonstrate that it was deposited under shallow marine conditions in an epicontinental sea (Anderton et al., 1979; Martill

\& Hudson, 1991; Cope, Ingham \& Rawson, 1992). Plant material found within the formation was

transported into a marine depositional setting from surrounding landmasses of which the nearest was

al., manuscript in progress). These specimens are also preserved in pyrite and calcium carbonate,

\section{Results}


189 burial taphonomic decomposition or damage. It is externally complete, with the specimen partially encased in clay from its depositional environment. The following description is based primarily on BU 5265, augmented by additional information from BU 5266 where available.

\section{Gross morphology}

194

The ovules are 16.8-21.6 mm long and 17.9-21.9 $\mathrm{mm}$ in maximum diameter (1/3 of the ovule length from base), and comprises a ribbed integument with a distal micropyle surrounding a central nucellus (Figs. 3, 6, 7). The integument is ovate-orbicular in longitudinal section with a bluntly rounded chalaza, tapering to a pointed apex (Figs. 3, 6A-C, 7C, D, 8A, 9A-C). It is circular in cross-section with prominent ribs (Figs. 3C, D, 6D-F, 7A, B, 8, 9G-I). The chalaza is flattened and 6.0-6.7 × 7.5-11.3 mm wide, with a 4.3-4.6 $\times 6.6-7.2 \mathrm{~mm}$ concave base that marks the position of attachment to the parent plant (Figs. $3 \mathrm{C}$, 4A, C, D). The three-layered integument lacks an external epidermis, even where the fossils are encased in the clay matrix. This observation suggests it was absent at the time of fossilization, and that the ovule had undergone some prior decay. The outer integumental layer is thin, and comprises radially aligned thick-walled cells - we consider this to be an outer sarcotesta (Figs. 6, 7, 9D-I). By contrast, the thicker middle layer consists of thin walled parenchyma cells, which we propose is an inner sarcotesta (Figs. 6, 7, 9D-I, 10A, B). The innermost integumentary layer contains thin-walled parenchyma cells organized in 2-5 rows. Individual cells are elongate here, and aligned parallel to the ovule circumference - we consider this layer to be the endotesta (Figs. 6, 7, 9D-F, C, 10B). A longitudinal interior integumentary groove, approximately $1.4 \mathrm{~mm}$ wide and more pronounced at the apex and bisecting the micropyle region, aligns with two of the integumentary ribs (Fig. 11). The nucellus is free from the integument but partially collapsed in BU 5265 (Fig. 6A-C). It is seen to follow the integumentary margin in BU 5266 (Figs. 7, 10A, B). The nucellus envelops a single functional megaspore and has an apical nucellar beak (Figs. 6 , 7C, D). No vascular tissues have been identified in either seed. Between two of the ribs along the 
213 midpoint of BU 5265 (arrowed on Fig. 3B, D), a rounded but irregular hole approximately $1 \mathrm{~mm}$ in

214 diameter penetrates into the specimen's interior. We interpret this feature as early post-mortem boring

215 by an organism that cut through all of the seed layers prior to permineralization.

216

\section{Integument}

218 The integument of both specimens has 12 prominent ribs, each $2.44-4.5 \mathrm{~mm}(\bar{x} 3.39 \mathrm{~mm} ; \mathrm{n}=6)$ wide and 0.6-0.9 mm ( $\bar{x} 0.75 \mathrm{~mm} ; \mathrm{n}=6)$ high (Figs. 3, 4). These start at the base of the ovule and some extend for the entire length; residual sediment is retained in some furrows between adjacent ribs (Figs. 3, 8; Model S1, S2; Video S2, S3). In the bottom 1/3 of the ovule, ribs are narrower and shorter than they are apically integument is $\sim 1.2-2.5 \mathrm{~mm}$ thick in the furrows, increasing to $\sim 2.7-3.5 \mathrm{~mm}$ in the centre of ribs (Figs. 3, 8).

The outermost integument - that of the outer sarcotesta - is thin, typically $0.17-0.46 \mathrm{~mm}$ (Figs. 6, 7A, fibrous palisade (Fig. 9D-I). Individual cells here are $\sim 52-72 \mu \mathrm{m}$ long and $\sim 16-32 \mu \mathrm{m}$ wide.

The middle and thickest integumentary layer — that of the inner sarcotesta - is readily distinguished in the furrows as its cells are orientated perpendicular to the outer sarcotesta (Fig. 9G-I). On the ribs the inner and outer sarcotesta boundary is less distinct as the cells of both layers are parallel (Fig. 9D-I). The inner sarcotesta contains large, isodiametric parenchyma cells, 50-68 $\mu \mathrm{m}$ in diameter and with cell walls 
237 sarcotesta is symmetrical along the rib midline where they are aligned towards the outside edge of the

238 rib, whereas in the furrows the cells are organized perpendicular to the rib orientation (Figs. 9D-I, 10B).

239 The central portion of each rib has the largest cells; size decreases and shape becomes more elongated

240 towards the outer and inner margins (Fig. 9G-I).

241

242 Endotestal cells are typically poorly preserved. Where complete, the layer is 50-180 $\mu \mathrm{m}$ thick and comprises 2-5 rows of small, thin-walled parenchyma cells that are elongated parallel to the ovule circumference (Figs. 9D-I, 10B). These line the integumentary cavity, and individual cells range from 47$91 \mu \mathrm{m}(\overline{\mathrm{x}}=71 \mu \mathrm{m} ; \mathrm{n}=20)$ in length, and 16-36 $\mu \mathrm{m}(\overline{\mathrm{x}}=27 \mu \mathrm{m} ; \mathrm{n}=20)$ in width. Cell walls are $8-14 \mu \mathrm{m}(\overline{\mathrm{x}}=$ $11 \mu \mathrm{m} ; \mathrm{n}=40$ ) thick (Fig. 9D-I). The anatomy at the internal groove is poorly preserved at the apex, and basally is physically missing (Figs. 11, S1 A, B). The interior morphology of the integument shows a longitudinal groove that bisects the micropyle region, and is $1.35-1.5 \mathrm{~mm}$ wide at this point (Fig. 11).

The groove measures $\sim 7.0 \mathrm{~mm}$ in length and $\sim 1.0 \mathrm{~mm}$ in height (Fig. 11). This feature becomes less pronounced as it descends from the apex, terminating towards the ovule base. Lateral compression of the seed has distorted the lower integument making determination of the indent in the lower ovule regions difficult (Figs. 11, S1 A, B, E). The micropyle is $0.8 \mathrm{~mm}$ in diameter (Fig. 12B-F).

\section{Nucellus and megaspore}

255

256

257 258 259
Where preserved, the nucellus - including the nucellar apex and the integumentary micropyle - is heavily encrusted and infilled with pyrite (Figs. 9A-C, 10D). This leaves only a faint residue of coalified material, visible under XMT, marking the position of the cellular membranes (Figs. 7B, C, 9A-F). Individual cells are not preserved (Figs. 6A-F, 9A-C; Video S1). 
260 The nucellus is $10.7-13.9 \mathrm{~mm}$ long (Figs. 6A-C, 12C) and a maximum of $8.2-8.4 \mathrm{~mm}$ wide (Figs. 6A-C,

261 10C). It is unicellular and 18-49 $\mu \mathrm{m}$ thick, its cells averaging $19 \times 33 \mu \mathrm{m}$ (Fig. 10E, F). The structure

262 closely follows the integument but has collapsed and shrunk in places (Figs. 10A, B, D, 11A, B). Pyrite

263 growth enveloping the nucellar membrane makes the original position of the nucellus uncertain (Figs. 6,

264 10A, E). However, we note it is adnate to the base of the integument in both specimens (Figs. 6, 7) and is

265 in very close association with the integumentary wall throughout BU 5266 (Figs. 7, 10A, B, E) except

266 toward the apex (Fig. 10D). The nucellar apex is situated directly below, and protrudes into the

267 integumentary micropyle (Figs. 6A-C, 9A-C, 12B-F). It comprises a small pollen chamber and distally a

268 conical nucellar beak (Figs. $6 \mathrm{~A}-\mathrm{C}, 9 \mathrm{~A}-\mathrm{C}, 12 \mathrm{~B}-\mathrm{F}$ ) that is $0.74 \mathrm{~mm}$ high, and $0.42 \mathrm{~mm}$ wide at it base,

269 narrowing to an apex $0.14 \mathrm{~mm}$ wide. The wall of the nucellar beak is $25-35 \mu \mathrm{m}$ thick, and the floor in

270 contact with the underlying nucellus is $\sim 20 \mu \mathrm{m}$ thick (Figs. 9A-C, 12E).

271

272 Within the nucellus of BU 5266 is a megaspore membrane (Fig. 10F), preserved by (and largely filled zone of preserved cells $\sim 32 \mu \mathrm{m}$ wide is interpreted as gametophytic tissue (Fig. 10G). Archaeogonial tissues have not been identified.

\section{Systematic Palaeobotany}

Superdivision SPERMATOPHYA

Division CYCADOPHYTA Bessey (1907)

Class CYCADOPSIDA Brongniart (1843)

Order CYCADALES Pers. ex. Bercht. \& J. Presl (1820) 
Oxfordiana motturii gen. et sp. nov. ART Spencer \& J Hilton

Generic Diagnosis: Anatomically preserved ovule with bilateral symmetry, ovate-orbicular in longitudinal section, circular in external cross-section, with pronounced longitudinal ribs and internal integumentary groove dividing the seed coat into two valves. Ribs rise from a flattened, concave base, with central attachment scar, extending to a pointed apex with conical micropyle. Integument three layered. Nucellus attached to integument at base; nucellar apex comprising a small pollen chamber and nucellar beak.

291

292 Specific Diagnosis: Twelve ribs rounded in profile, narrower in basal $1 / 3$ of ovule with adjacent ribs merging together. Less pronounced in apical $1 / 3$ of ovule. Integument thickest at centre of ribs. Thinning laterally and thinnest in furrows between ribs. Outer integument forming thin, fibrous palisade of elongate, thick-walled cells aligned perpendicular to ovule body. Middle integument thickest, comprising variable-sized isodiametric parenchyma cells aligned perpendicular to outer integument in rib furrows, becoming parallel within ribs, thus symmetrical along the rib mid-line. Inner integumentary layer represented by 2-5 rows of small, thin-walled, elongate parenchyma cells aligned with ovule circumference. Integument with conical micropyle. Pollen chamber with small nucellar beak that projects into micropyle.

301 Localities: Dix Pit near Stanton Harcourt (51.743 N, -1.420 W; OS Grid Ref: SP 412 049) and Marston Maisey, near Cirencester (51.667 N, -1.806 W; OS Grid Ref: SU 135 965), UK.

Horizon: Uppermost Stewartby Mbr to lowermost Weymouth Mbr of the Oxford Clay Fm. 
Stratigraphy and age: Quenstedtocdras lambertii ammonite subzone of the Quenstedtocdras lambertii Biozone to Cardioceras mariae Biozone; latest Callovian Stage (Middle Jurassic) to earliest Oxfordian Stage (Upper Jurassic).

Holotype: BU 5265 consisting of 4 parts (BU 5265.1-4)

Paratype: BU 5266

Etymology: The generic epithet is derived from the Oxford Clay Fm from which the species is recognized. The specific epithet is named in honour of Julian Motture, who collected the type specimen.

Depository: Lapworth Museum of Geology, University of Birmingham.

Life Science Identifier: XXXX

\section{Discussion}

\section{Comparison with other gymnosperm ovules and evolutionary implications}

Oxfordiana motturii gen. et sp. nov. is a large, bilaterally symmetrical, ribbed ovule that has similarities

in terms of its gross morphology with seeds produced by several taxonomic groups. It is closest in morphology to the Jurassic ovule Cycadeospermum Saporta (Saporta, 1875) from the Oxfordian Stage of

France. The diagnosis of Saporta includes ovate ovules, some of which are ovate-oblong, possess longitudinal ribs, have a rounded base with an attachment scar, and have a tapered apex (e.g. Fig. 13). 
330 However, Saporta also indicated that the longitudinal ribs may in fact be angular vegetative leaflets

331 forming a cupule around the ovule (Saporta, 1875, pg. 237); an interpretation we consider unsupported

332 speculation. Cycadeospermum schlumbergeri Saporta (Saporta 1875; Plate CXVII, Figs. 11, 12) is

333 incompletely characterized and has not been described in detail. Nevertheless, Saporta's description

334 and his drawings of the species demonstrate it to have an external morphology that is similar to the

335 species documented here (Fig. 13 A, B). Cycadeospermum schlumbergeri is ovate-conical, with a

336 truncated base with an attachment scar. From the four-keeled base, ribs form that extend to the ovule's

337 apex (Saporta, 1875). Ovules of this species are 1.6-2.4 cm long, and 1.3-1.9 cm wide, and hence are of

338 similar shape and size to the British specimens described here. Anatomical details are not known in the

339 French specimens, preventing more detailed comparison. Unfortunately, the $C$. schlumbergeri

340 specimens on which Saporta based his account belonged to private collections and do not appear to

341 have been deposited in a museum to allow future comparisons. We can at least state that

342 Cycadeospermum schlumbergeri comes from a coeval depositional unit, adjacent to the shallow marine

343 Channel Basin, and is potentially derived from the Armorica Massive. Without access to the type

344 specimen of the French species for restudy, and using only the rudimentary illustrations and non-

345 histological descriptions available from Saporta's work, we consider it preferable to describe the fossils

346 presented here as a new genus. Saporta's concept of Cycadeospermum is based entirely on gross

347 external morphology with no histological preservation known, thereby differentiating it sufficiently from

348 Oxfordiana erected to contain the Oxford Clay Fm ovules possessing anatomical preservation.

The ovules described here bear a general resemblance to those of Cycadales, a group that can be traced

351 back to the Palaeozoic Era, reached peak diversity during the Jurassic and Cretaceous periods, apparently underwent a more recent evolutionary radiation (Nagalingum et al., 2011), and includes 
354 traced back into the Mesozoic Era (Nagalingum et al., 2011). All cycad seeds present a unique

355 combination of features among seed plants (Brenner, Stevenson \& Twigg, 2003) and in extant plants

356 display two distinct types of ovule morphology (Stevenson, 1990). Platyspermic ovules, restricted to

357 Cycas, among living cycads, are oval to distinctly flattened, bi-lobed, with an apical depression, whereas

358 all other extant cycads have radiospermic ovules. Ovules of Cycadeocarpus from the Jurassic of Haida

359 Guai (previously known as Queen Charlotte Islands), Canada described by Dawson (1872) and

360 subsequently re-investigated by Chaloner and Hemsley (1992), are at 4-5.25 × 4.25-4.5 cm substantially

361 larger than 0 . motturrii. They possess a series of $\sim 18$ canals within the integumentary tissue surrounding

362 the micropyle (i.e. coronula), a feature absent from the Oxford Clay Fm specimens, the genus Cycas, as

363 well as a currently unnamed species of cycad seeds from the same locality as Cycadeocarpus (Rothwell,

364 Stockey \& Stevenson, 2017). The bilateral symmetry (more specifically, $180^{\circ}$ rotational symmetry of

365 Rothwell, 1986) is intimately associated with the germination mechanism of Cycas and probably also

366 with the anatomically preserved Jurassic fossil seeds. There are, however, notable morphological

367 differences between O. motturri and all other Mesozoic Era cycads. Ovules of the Jurassic

368 megasporophyll Beania Carruthers are nearly circular, lack prominent longitudinal ribbing, and are

369 smaller than these Oxford Clay Fm ovules. For example, Beania gracilis is $\sim 16 \mathrm{~mm}$ long and $\sim 13 \mathrm{~mm}$

370 wide, and Beania mamayi is $\sim 4 \mathrm{~mm}$ wide (Harris, 1964). Furthermore, although Beania species are

371 known only from compression/impression fossils, precluding full comparisons, B. mamayi has resin

372 bodies in the integument, and both $B$. gracilis and B. mamayi have cuticles that demonstrate the

373 presence of a stony layer (Harris, 1964), features that are absent from the Oxford Clay Fm ovules. In

374 terms of comparison with extant, broadly similar cycads, ovules of Dioon (Chamberlain, 1906), Bowenia

375 (Kershaw, 1912) and Cycas (Stopes, 1905; Seward, 1917) have an integument with a uniseriate

376 epidermis, an outer parenchymatous sarcotesta, a stony sclerotesta, and innermost fleshy endotesta.

377 Additionally, in most cycads the endotesta has a similar thickness to the stony sclerotesta, and does not 
378

appear to collapse at maturity as in most other gymnosperm ovules (Seward, 1917; Taylor, Taylor \& Krings, 2009). However, these genera possess a twin vascular system with bundles in the sarcotesta and endotesta extending towards the micropyle (Kershaw, 1912; Coulter \& Chamberlain, 1938). This organisation differs from Oxfordiana, where vascular bundles have not been found in the sarcotesta and endotesta. We note that Dioon has an abscission layer (Chamberlain, 1906) where it sheds from the sporophyll, which results in a chalazal scar similar to the basal feature in Oxfordiana.

Cycas is unique among the extant cycads in having a novel germination mechanism in which the seed coat splits into two equal valves at the micropylar end (Stevenson, 1990) to allow germination. This appears to be comparable with the integumentary groove in the apex of Oxfordiana, and also with the valved integument of the unnamed seed from Haida Gwai (Rothwell, Stockey \& Stevenson, 2017) which we consider also to have facilitated germination. These characters appear to represent a common germination mechanism, found nowhere else outside the Cycadeaceae among living and fossil seed plants. If this germination mechanism represents a synapomorphy of the Cycadaceae, then the novel integumentary histologies and vascular systems of Oxfordiana and the unnamed seed from Haida Gwai suggest that the fossil taxa represent stem group representatives of the Cycadaceae.

Oxfordiana motturii also superficially resembles the ovules of Ginkgoales. These are readily identified through the presence of a dense sclerotesta with 2-3 ribs, and a ribless fleshy sarcotesta (Seward \& Gowan, 1900). Czeckanowskialeans are a group reputedly closely allied with Ginkgoales (e.g. Taylor, Taylor \& Krings, 2009). Their ovules, assigned to Leptostrobus Heer, are borne in $5 \mathrm{~mm}$-long seedcapsules, each of which contains up to five ovules. These are significantly smaller than the specimens presented here (Heer, 1876; Harris, Millington \& Miller, 1974; Liu, Li \& Wang, 2006). Anatomical features of czecknowskialeans are unknown, preventing further comparison. 
403 Pteridosperms were present during the Mesozoic Era, but their ovules were much smaller than the 404 Oxford Clay Fm specimens. For instance, ovules of the Caytoniales (Reymanówna, 1973) and

Pentoxylales (Sahni, 1948; Bose, Pal \& Harris, 1985; Drinnan \& Chambers, 1985; Césari et al., 1998) are

$\sim 2 \mathrm{~mm}$ long. Those of the pentoxylalean genus Carnoconites Srivastava have a thick fleshy sarcotesta,

and are have been described as both platyspermic with two sclerotestal ribs (Srivastava, 1935;

Williamsoniaceae (Williamsonia Carruthers) ovules are larger - up to $8 \mathrm{~mm}$ long - and circular, have

(Sharma, 1970; Sharma, 1980; Stockey \& Rothwell, 2003).

417 The ovules of Triassic Petriellales are triangular and significantly smaller ( $1 \mathrm{~mm}$ diameter) than the

Oxford Clay Fm ovules (Taylor, Fueyo \& Taylor, 1994). Corystospermales, also most common in the

Triassic, differ from these specimens as they are considerably smaller (e.g. seeds of Umkomasia

macleanii $\mathrm{H} . \mathrm{H}$. Thomas are $5 \mathrm{~mm}$ long), bilaterally symmetrical, and possess a single integumentary layer 
425 The ovules described here also differ from gnetalean plants. All extant (Ephedra L., Gnetum L., and

426 Welwitschia Hooker) and most extinct gnetalean genera, have chlamydospermous ovules, with one or

427 more distinctive seed envelopes or bracteloles enclosing the ovule (Taylor, Taylor \& Krings, 2009; Friis,

428 Pedersen \& Crane, 2014). They also possess an extended micropylar tube protruding above the seed

429 envelope or bracteoles (Friis, Pedersen \& Crane, 2013). We note that ovules of the extinct species

430 Protoephedrites eamesii Rothwell \& Stockey (Rothwell \& Stockey, 2013) lack an outer seed envelope and

431 have a diminutive micropylar tube but are significantly smaller than the Oxford Clay Fm ovules. In

432 general, gnetalean ovules possess thinner membranous and relatively undifferentiated integuments

433 than those presented here (Rothwell \& Stockey, 2013; Friis, Pedersen \& Crane, 2014).

434

We have also compared the Oxford Clay Fm ovules with older species. They are superficially similar to

the ovules of Palaeozoic Era medullosan pteridosperms, in sharing large size and similar nucellar apex

structure (Taylor, Taylor \& Krings, 2009; Spencer et al., 2013). Nevertheless, medullosan ovules have a

prominent sclerotesta (stony layer) that is absent from the Oxford Clay Fm ovules. In addition to having

radial, rather than bilateral symmetry, all of the eight well-characterized genera of anatomically

preserved medullosan ovules within the traditional trigonocarpalean group (Seward, 1917) differ from

the Oxford Clay Fm specimens in being radially symmetrical and in possessing a ribbed sclerotesta

442 (Spencer et al., 2013; Spencer, Hilton \& Sutton, 2013). Furthermore, Polylophospermum Brongniart,

Polypterospermum Brongniart (Brongniart, 1874; Combourieu \& Galtier, 1985), Hexapterospermum

Brongniart (Brongniart, 1874; Taylor, 1966) and Hexaloba Dunn, Mapes \& Rothwell (Dunn, Mapes \&

Rothwell, 2002) have six-lobes in transverse section, whereas Pachytesta Brongniart and

446 Stephanospermum Brongniart have three prominent ribs (Brongniart, 1874). Codonospermum

447 Brongniart is distinguished by a two-chambered integumentary cavity with the nucellus and associated 
449 1985). Finally, Rhynchosperma Taylor \& Eggert differs in its possession of apical integumentary

450 appendages and bulbous hollow lobes as part of a stellate micropylar canal (Taylor \& Eggert, 1967;

451 Dunn, Rothwell \& Mapes, 2002). We also note that medullosan pteridosperms are only known from the

452 Carboniferous and Permian periods (Phillips, 1980; Hilton \& Cleal, 2007), so are considerably older than 453 the Oxford Clay Fm ovules.

454

Based on these comparisons, it is clear that $O$. motturii is externally morphologically similar, to the coeval Cycadeospermum schlumbergeri, a comparatively poorly characterized species from which anatomical details are unknown. However, as previously stated, we view Saporta's genus Cycadeospermum as having been established for ovules without histological preservation, and thus precluding assignment of the present specimens (Bateman \& Hilton, 2009). The specimens described here differ from all other known fossil and extant seeds. As such, we have created a new genus and species to accommodate them, Oxfordiana motturii ART Spencer \& J Hilton gen. et sp. nov. Although Saporta (1875) considered Cycadeospermum to be a cycad, this conclusion is not supported by the limited information currently available on the genus. By contrast, the structure of the integument, bilateral symmetry, and presence of an integumentary groove all suggest that Oxfordiana was a member of the Cycadales and a member of the stem-group lineage leading to the extant genus Cycas, which exhibits the same features. This conclusion agrees with the postulated Lower-Middle Jurassic divergence of Cycas from other extant genera within the Cycadales based on molecular clock studies (Nagalingum et al., 2011).

\section{Functional morphology and herbivory}

471 The seeds described here are larger than the majority of other recorded Jurassic seeds, an exception

472 being some cycad seeds from the Jurassic of Haida Guai (Dawson, 1872; Chaloner \& Hemsley, 1992). 
473 Within plants there is a trade-off between seed size and number: species that produce large seeds tend

474 to do so in low numbers given a similar resource investment (e.g. Westoby, Jurado \& Leishman, 1992).

475 Larger seeds have greater independence from the environment, due to their greater resources available

476 to support the initial stages of growth, for example under shaded conditions and periodic drought

477 (Foster, 1986; Westoby, Jurado \& Leishman, 1992; Werker, 1997). Thus, we conclude that, each

478 propagule has a greater chance of survival. We postulate that, Oxfordiana seeds were probably

479 produced in small numbers, and would have had considerable environmental independence during their 480 early development. Furthermore, large seeds, such as Oxfordiana, are typical of non-ruderal rather than 481 pioneering plants because they are limited to animal or water dispersal, being too large and heavy for 482 effective transport by wind (Tiffney, 2004).

483

484 Generally, large seeds represent preferential targets for herbivory because they are more nutritious 485 (Tiffney, 2004; Keddy, 2007). This would have been true of Oxfordiana, which nevertheless lacks obvious herbivore deterrents such as resin bodies or glands (Werker, 1997; Tiffney, 2004). However, it is possible that the integument may have contained toxins resembling those of modern cycads (Brenner, Stevenson \& Twigg, 2003).

\section{Reproductive biology}

491

492

An integumentary groove as seen in Oxfordiana also occurs within the Cycadales, where it is characteristic of the extant genus Cycas in which ovules are bilaterally symmetrical (Stevenson, 1990). In Cycas this integumentary groove allows the seed to split open into two valves through the micropyle facilitating germination, a feature we interpret as also present in Oxfordiana. This situation is distinct from other extant cycads in which the embryo forces its way through the seed coat rupturing the micropylar region (Stevenson, 1990). Although we do not know the germination mechanism for 
497 Cycadeospermum (Fig. 13), we consider it probable that it too germinated through an apical groove

498 based on its overall similarity with Oxfordiana.

499

500 The nucellar apex of Oxfordiana comprises a small pollen chamber and short nucellar beak, situated

501 directly beneath a narrow integumentary micropylar canal. This is structurally identical to the ovules of

502 extant Cycadales and Ginkgoales (Sporne, 1971; Singh, 1978). Post-pollination sealing of the

503 megagametophyte in these gymnosperms is callistophytalean in nature (Serbet \& Rothwell, 1995);

504 closure occurs through both the nucellar beak and integumentary micropyle. The same form of ovule-

505 sealing is also present within the extinct callistophytalean pteridosperms, Cordaitales and

506 Glossopteridales, and hence differs from the hydrasperman and medullosan ovule-sealing patterns,

507 which do not involve the post-pollination closing of integumentary tissue (Serbet \& Rothwell, 1995).

508 Cladistic analysis suggests that the callistophytalean pattern was also present in the extinct

509 pteridosperm groups Peltaspermales, Corystospermales and Caytoniales (Rothwell \& Serbet, 1994;

510 Serbet \& Rothwell, 1995). This distribution implies that it is symplesiomorphic for crown-group

511 gymnosperms. By contrast, a coniferalean pattern is present in conifers (except Emporia), Gnetales, and

512 the extinct Pentoxylales. Here sealing is achieved by the integument only, the pollen chamber apex

513 remaining open post-pollination (Serbet \& Rothwell, 1995). Oxfordiana lacks the central column and

514 large pollen chamber found in hydrasperman-pattern ovules, but has the small pollen chamber and

515 nucellar apex characteristic of the medullosan and callistophytalean patterns. We cannot determine in

516 Oxfordiana if the integument was sealed, as in callistophytalan ovules, or open like that of medullosan

517 ovules. Nevertheless, medullosan ovules are only known from the Palaeozoic Era and have characteristic

518 integumentary structures lacking in Oxfordiana, we consider it more probable that Oxfordiana had post-

519 pollination sealing that followed the callistophytalean-pattern.

520 
521 Source flora, and mechanism of transportation into marine depositional setting

522 The source area(s) of the terrestrial fossil in the marine Oxford Clay Fm sites at Dix Pit and Marston

523 Maisey most likely occupied the Anglo-Brabant and Welsh landmasses (based on data from Cope,

524 Ingham \& Rawson, 1992). Current palaeographic models imply a minimum of 60-70 km transport prior

525 to deposition. Although slightly older, the Middle Jurassic Stonefield flora (e.g. Seward, 1904; Kendall,

526 1948; Cleal \& Rees, 2003) is palaeogeographically closest to the Oxford Clay Fm sites. Cleal \& Rees

527 (2003) suggested that it represents a flora from coastal slopes surrounding the marine basin that was

528 dominated by araucarian and cheirolepidiacean conifers, together with the probable gymnosperm

529 Pelourdea Seward (1917). Rarer fossil plants from the site include Pinaceae (e.g. Brachyphyllum

530 Bongniart), Bennettitales, Caytoniales, eusporangiate ferns (Dipteridaceae, Matoniaceae,

531 Dicksoniaceae), Corystospermales, and various foliage categories resembling Cycadales and Ginkgoales

532 (Brongniart, 1828; Cleal \& Rees, 2003). The flora is thus interpreted as sampling lowland coastal habitats

533 subjected to periodic water stress (Francis, 1983), although the Pelourdea leaves probably required

534 fluvial transport from further inland (Cleal \& Rees, 2003). Despite this, the absence from Stonefield of

535 plants such as sphenophytes, ferns and Czekanowskiales, interpreted to have favoured freshwater and

536 wetland habits, may reflect preservation after short transportation due to the more fragile nature of the

537 plant remains (Cleal \& Rees, 2003). Le Couls et al. (2016) documented an entire cycad plant crown

538 deposited in shallow marine sediments in the Tithonian of France that they interpreted to have

539 inhabited coastal dunes. Numerous British lagerstätte in addition to the Oxford Clay Fm also show

540 evidence of terrestrial plants in marine settings. These include those preserved at Bearreraig Bay

541 (Bateman, Morton \& Dower, 2000), Eathie (Wignall \& Pickering, 1993), and Freeth Wood (Rothwell et

542 al., 2007). Clearly, transportation of terrestrial plants into marine settings is widespread in the fossil

543 record. These extremely important occurrences provide windows into past terrestrial diversity that is

544 rarely preserved on land itself, but are limited in number (e.g. Taylor, Fueyo \& Taylor, 1994; Escapa, 
545 Cúneo \& Axsmith, 2008; Escapa \& Leslie, 2017); none has yet been identified in the Lower Jurassic (Fig.

546 1B) of England or Scotland. We contend that finding additional sites for anatomically preserved plants in

547 marine successions is important to the future development of palaeobotany.

548

549 Three mechanisms of transport from the Oxfordiana plant's growth environment to its deposition in a

550 shallow marine sea are possible. Water transportation could occur through individual seed floatation or

551 larger scale vegetational rafting (e.g. Carlquist, 1981; Johansen \& Hytteborn, 2001), though dispersal by

552 animal gut is also feasible (e.g. Molnar \& Cifford, 2001; Zhou \& Zhang, 2002). The size and weight of the

553 ovules precludes wind transportation. We address these options individually below.

554

555

The floating capacity of seeds was investigated by Guppy (1906) and Praeger (1913), who compiled a list

556 of seed buoyancy determined through experimentation. These studies on various floating seeds of

557 modern coastal plants categorized three groups with contrasting floatation methods, and determined

558 that seed size does not affect the ability to float (Guppy, 1906). Two of these groups display non-

559 adaptive/mechanical floatation, and possess structures also seen in inland seeds (although these were

560 generally reported to have little or no floatation power). The first group includes ovules that float

561 because of unoccupied space in the cavity of the seed, resulting from shrinkage of the gametophyte

562 away from the integument. In these species no other part of the structure possesses independent

563 floatation structures (e.g. the seeds of the cycad Cycas revoluta; Giddy, 1974; Dehgan \& Yuen, 1983).

564 The second group floats either due to buoyant kernels or through layers of air-bearing tissue within the

565 shell (e.g. the large, 2-4 cm, single-seeded eudicot Calophyllum inophyllum L.). Guppy (1906) concluded

566 that these two categories, although able to float, have no specific adaptations for dispersal by water. In

567 contrast, the third group represents plants that have become specifically adapted for water current

568 dispersal. These seeds universally gain floatation power from air-bearing tissue in their seed-coats, for 
569 instance the extra 'spongy' parenchymatous tissue of the cycadalean Cycas circinalis L., which can float

570 for between five weeks and three months (Ridley, 1930; Gunn \& Dennis, 1976; Dehgan \& Yuen, 1983).

571

572 Assuming that the Oxford Clay Fm ovules represent the full range of tissues present in life, there are

573 options for placing the species within Guppy's floatation categories. They cannot be placed in the third

574 group because no seed-coat air-pocket tissues were present in the Oxford Clay Fm ovules — rather,

575 their tissue layers are made of densely packed cells. This lack of floatation tissue also rules out the

576 second group. Hence, the Oxford Clay Fm ovules must belong to the first group - seeds that have a large

577 air-tight internal cavity, as seen in many modern cycad species lacking specialized floatation tissue. In

578 the fossil ovules the gametophytic tissue was not fully expanded forming an air-cavity. In some cycad

579 species low gametophytic growth and the corresponding ability to float has been linked to seed viability

580 - in which fertilized seeds tend to sink (Dehgan \& Yuen, 1983). If a similar mechanism applied to the

581 Oxford Clay Fm ovules, it would imply that they were at a pre-fertilization stage.

582

583 Another method of transport from source to depositional site is vegetational rafting. This form of

584 chance dispersal relies on seeds being carried out to sea by rafts of floating plant debris (Carlquist,

585 1981). Little work has been done to study seed-deposition through vegetational rafting; the emphasis of

586 most published studies is on the trans-ocean transport of fauna. However, one study has demonstrated

587 that some modern-day coastal plants use rafting to transport their seeds in the North Atlantic/Arctic

588 Ocean (Johansen \& Hytteborn, 2001). Today, rafts form regularly at higher latitudes through river

589 transportation from large amounts of floating wood and entangled vegetation. This occurs with

590 decreasing regularity at lower latitudes due to increased inter-annual variation in the availability of

591 wood (Gibson, Atkinson \& Gordon, 2006). We note that rafting is a possibility here: the fossil wood 
592 found within the Oxford Clay Fm, occurring as logs up to $1 \mathrm{~m}$ long and $80 \mathrm{~cm}$ in diameter (Porter, 1863).

593 Hence, the material for raft building existed, and was circulating in the basin waters prior to deposition.

594

595

During the Jurassic, large land-dwelling herbivores, such as prosauropod (e.g. Weigelt, 1930) and

sauropod (e.g. Stokes, 1964; Mohabey, 2001) dinosaurs, became the dominant terrestrial herbivores

597 (Tiffney, 2004). The dentition of these suggests they relied on gut gastroliths coupled with gut

fermentation to break down the plant material ingested (Farlow, 1987). This style of digestion probably

allowed whole seeds to enter the gut (Tiffney, 2004; Mustoe, 2007). That these animals lived on land

reduces the possibility that they were the transport vector for the ovules while alive. In death, however,

601

they evidently reached the marine Oxford Clay Fm depositional zone, as the unit contains abundant

602

body fossils (see Martill \& Hudson, 1991, and references therein). Therefore, the possibility - albeit a

603

very remote one - exists that during the decomposition of a dinosaur at sea, undigested plant matter

604

was released into the sea. Pterosaurs were present in the marine environment. Although study of their

605

dentition suggests the group were primarily suited for piscivory or insectivory, they have been

606

implicated as potentially important seed dispersers by Flemings and Lips (1991). The piscivorous

607

pterosaur Rhamphorhynchus is known from the Oxford Clay Fm (Martill et al., 1994), but frugivores,

such as Tapejara (Wellnhofer, 1991; Wang \& Zhou, 2003), are not currently recognized before the

Cretaceous. The oldest bird-like fossil, Aurornis, from the Jurassic Callovian-Kimmeridgian stages of

610 China (Godefroit et al., 2013), is coeval with the Oxford Clay Fm ovules; however, doubt has been cast

611 on the authenticity of this early date (Balter, 2013). The next oldest fossil avian, Archaeopteryx, is

612 Tithonian in age (so significantly postdates deposition of the Oxford Clay Fm) and is interpreted to have

613 been carnivorous (Ostrom, 1976). However, seed-eating birds are known from the Lower Cretaceous of

614 China (Zhou \& Zhang, 2002; Zhou, 2004). They consumed small, circular (8-10 mm long) seeds of the

615 Carpolithus-type (Zhou \& Zhang, 2002); these are very different from the large seeds of Oxfordiania. 
616 Hence, we argue that dispersal of large seeds, such as Oxfordiana, into marine settings by winged

617 vertebrates is, based on current evidence, unlikely in the Jurassic.

618

619 Mode of preservation

620 The specimens described here have different modes of preservation. In the case of BU 5265, it appears

621 that rapid burial limited bacterial decomposition, thus preserving the ovule in an almost perfect state.

622 The lack of taphonomic degradation during transportation to the depositional site is, however,

623 intriguing. If the ovule floated via a self-contained mechanism, until becoming inundated and sinking

624 (see above), the effects of salt water and bacterial degradation were minimal. It is possible, if this

625 scenario is true, that the ovule seed-coat may have evolved to be both waterproof (i.e. a

626 impermeable/hard seed; Barton, 1967) and to have possessed a degree of antibacterial properties (e.g.

627 high tannin levels; Roth, 1987). Fossil data are not able to add any support to this conjecture; no cells

628 have been found that could be defined as wax- or oil-producing for aiding waterproofing, nor can the

629 chemical properties of the seed-coat be deduced. If transportation occurred through rafting, the ovule

630 could have remained relatively dry until the point of inundation (when the raft breaks up or sinks).

631 Assuming that the seed did not possess any adaptations for hydrochory, this phenomenon could have

632 extended the time before taphonomic degradation became a significant factor, and also allowed the

633 seed to sink rapidly to the sea floor for burial.

634

635 In contrast, specimen BU 5266 has more extensive pyritization, including disruptive pyrite growth in the

636 plant tissues (Figs. 4, 7A, B), suggesting a greater period of exposure to salt water prior to burial and

637 permineralization. Water saturation of the ovule would have resulted in voids filling with sea-water. If

638 transport occurred through floatation, this would have led to sinking and burial. If rafting was involved, 
639 the ovule may have remained on the sea surface whilst fully saturated - ideal conditions for bacterial

640 growth (i.e. warm, high oxygen, moist).

641

642 After sinking and burial in seafloor sediments, both ovules underwent preservation in two distinct

643 mineralization phases: first rapid pyritization, followed by a second carbonate phase. The latest

644 Callovian Stage to early Oxfordian Stage seafloor is interpreted to have been tens of meters deep in this

645 area (Martill \& Hudson, 1991), and has been described as having a dominantly firm substrate. Reports

646 suggest that pockets of 'soupy' sediment existed, within which rapid burial of organic specimens could

647 take place (Martill \& Hudson, 1991; Wilby et al., 2004). Previous studies of taphonomic processes and

648 pyrite preservation in the Oxford Clay Fm have focused on the fauna (e.g. ammonites, belemnites)

649 within these organic-rich sediments (Martill \& Hudson, 1991).

650

651 The process of pyritization within the Oxford Clay Fm commenced through anoxia of the host sediment,

652 which causes sulphate reduction of carbon within the sediment (6-16\%; Kenig et al., 1994; Raiswell, 653 1997). The sulphate produced reacts with iron in the sediment to yield iron monosulphate (FeS). This

654 subsequently reacts with hydrogen sulphide created by sulphate-reducing bacteria decomposing 655 sedimentary organic matter (Rickard \& Luther, 1997). A by-product of this process is increased water 656 alkalinity (Berner, 1970; Berner, 1984; Berner et al., 1985; Skyring, 1987). Iron monosulphate porewater 657 concentration increases, almost reaching saturation point - a process seen in modern continental 658 margin sediments (Raiswell, 1997). Precipitation of iron and sulphide minerals, such as mackinawite, or 659 direct pyrite precipitation results. For the Oxford Clay Fm ovules this represents the first phase of 660 mineralization, responsible for depositing pyrite within and around cell walls. These cells would have 661 been undergoing bacterial decay by sulphide reduction, while the ovule was becoming buried in 662 successive surface layers of the sediment (Fig. 14). 
664 At the same time as pyrite mineralization was occurring, due to the lower saturation of carbonate within 665 the porewater system, contemporaneously deposited shelly fauna (including ammonites and 666 belemnites) were undergoing carbonate shell dissolution and replacement by pyrite. Carbonate 667 dissolution and pyrite replacement would have occurred until such time as the carbonate concentration 668 increased, allowing direct precipitation of pyrite on to the shells as a coating (Raiswell, 1997). As the 669 Oxford Clay Fm ovules became buried at greater depth (1-10 m), over-saturation of iron decreased, 670 reducing the ability of pyrite to form and at the same time the carbonate saturation increased to 671 become over-saturated. Under a methanogenesis regime in this over-saturated state, deposition of 672 carbonate within the ovule void spaces occurred, while the pyrite deposition decreased and ultimately 673 terminated (Fig. 14).

674

675 Preservation of the ovules thus occurred through floating/rafting, then sinking into soft sediment, and 676 subsequent pyritization with secondary carbonate infilling. This series of events is unlikely to have 677 occurred regularly, and is one possible reason for the rarity of fossil seeds reported from the Oxford Clay 678 Fm despite its long history of fossil collecting (Martill and Hudson, 1991). We note also that the majority 679 of historic collecting may have been focused on the fauna rather than the flora, leading to a Kingdom680 level collecting bias. Preservation of these seeds is different from fossil woods preserved elsewhere in 681 the deposit where pyrite growth tends to be amorphous, and rarely preserves cellular features. We 682 suggest that these specimens concentrated sulphate-reducing bacteria into a closed microenvironment 683 that allowed exceptional preservation. By contrast, larger specimens, such as plant trunks and branches, 684 would have had more diffuse mineralization at lower rates over their extent. They probably also lacked 685 the sealed microenvironments required for exceptional preservation (Grimes et al., 2001; Grimes et al., 686 2002; Tibbs, Briggs \& Prössl, 2003). Finally, we would emphasize that pyritization does not preserve cell 
687 contents. Rather it envelops cell walls and tissue layers: an aggrading process that can make cell size 688 measurements using traditional optics difficult and may lead to exaggerated estimates. Using SRXMT 689 has here allowed us to overcome this taphonomic effect by measuring the carbonate preserved cell 690 walls embedded within the pyrite coatings (Figs. 6, 7, 9).

691

692 Conclusions

693 694

Oxfordiana motturrii gen. et sp. nov. is a distinctive gymnospermous ovule that differs from all other fossil and extant seeds, and is here placed within the Cycadales as a member of an extinct, stem-group lineage relative to the extant genus Cycas. We conclude that it had valvate germination through a distal integumentary groove, as well as a callistophytalean pattern of ovule-sealing. We also demonstrate that SRXMT can provide valuable new insights into sectioned fossil specimens and, in particular, their taphonomic history.

\section{Acknowledgements}

We thank the PeerJ editor R.M. Bateman for the constructive comments and suggestions that have helped in the revision of this manuscript. Additionally, the text was improved by insightful reviews from C.J. Cleal and an anonymous reviewer whom we thank. We thank Michael Drakopoulos, Nghia Vo, Christina Reinhard, Robert Atwood and Kaz Wanelik for their support and assistance during this beamtime. We thank Alice Spencer for help with Latin translations. This work constituted part of a doctoral research project for ARTS at Imperial College London for which Mark Sutton and members of the Earth Science and Engineering Department are thanked. 


\section{References}

710 Abràmoff MD, Magalhães PJ, Ram SJ. 2004. Image processing with ImageJ. Biophotonics International

711 11:36-42.

Anderton R, Bridges PH, Leeder MR, Sellwood BW. 1979. A dynamic stratigraphy of the British Isles. A study in crustal evolution. London, Boston, Sydney: George Allen and Unwin.

714

715

716

717

718

719

Axsmith BJ, Taylor EL, Taylor TN, Cuneo NR. 2000. New perspectives on the Mesozoic seed fern order Corystospermales based on attached organs from the Triassic of Antarctica. American Journal of Botany 87:757-768.

Balter M. 2013. Authenticity of China's fabulous fossils gets new scrutiny. Science 340:1153. DOI: 10.1126/science.340.6137.1153.

Barbacka M, van Konijnenburg-van Cittert JHA. 1998. Sun and shade leaves in two Jurassic species of Pteridosperms. Review of Palaeobotany and Palynology 103:209-221. DOI: 10.1016/S00346667(98)00036-0.

Barton LV. 1967. Bibliography of seeds. Columbia University Press.

Bateman RM, Hilton J. 2009. Palaeobotanical systematics for the phylogenetic age: applying organspecies, form-species and phylogenetic species concepts in a framework of reconstructed fossil and extant whole-plants. Taxon 58:1254-1280.

Bateman RM, Morton N. 1994. New petrified Middle Jurassic floras from nearshore marine sediments at Bearreraig, Skye. American Journal of Botany 81:88 [Abstract].

Bateman RM, Morton N, Dower BL. 2000. Early Middle Jurassic communities in northwest Scotland: Paleoecological and paleoclimatic significance. In: Hall R, Pulton T, eds. GeoResearch Forum 6 (Proceedings of the Fifth International Symposium on the Jurassic System). Zurich: TransTech Publications, 501-511.

von Berchtold F, Presl JS. 1820. O Prirozenosti Rostlin aneb Rostlinár. K dostánj u K.W. Endersa. 
733 Berner RA. 1970. Sedimentary pyrite formation. American Journal of Science 268:1-23.

734 Berner RA. 1984. Sedimentary pyrite formation: an update. Geochimica et Cosmochimica Acta 48:605-

735

736

737

738

739

740

741

742

743

744

745

746

747

748

749

750

751

752

753

754

755

756 615. DOI: 10.1016/0016-7037(84)90089-9.

Berner RA, Leeuw JWD, Spiro B, Murchison DG, Eglinton G. 1985. Sulphate reduction, organic matter decomposition and pyrite formation [and discussion]. Philosophical Transactions of the Royal Society of London A: Mathematical, Physical and Engineering Sciences 315:25-38. DOI: 10.1098/rsta.1985.0027.

Bessey CE. 1907. A synopsis of plant phyla. In: University Studies. Nebrask, USA: University of Nebrask, 275-373.

Bose MN, Pal PK, Harris TM. 1985. The Pentoxylon plant. Philosophical Transactions of the Royal Society of London B: Biological Sciences 310:77-108. DOI: 10.1098/rstb.1985.0100.

Brenner ED, Stevenson DW, Twigg RW. 2003. Cycads: evolutionary innovations and the role of plantderived neurotoxins. Trends in Plant Science 8:446-452. DOI: 10.1016/S1360-1385(03)00190-0.

Brongniart A. 1828. Prodrome d'une histoire des végétaux fossiles. Paris: F.G. Levrault.

Brongniart A. 1843. Énumération des genres de plantes cultivées au Musée d'histoire naturelle de Paris. Paris, France: J.-B. Bailliere.

Brongniart A. 1874. Études sur les graines fossiles trouvées à l'état silicifié dans le terrain houiller de Saint-Étienne. Annales des Sciences Naturelles, Botanique 5è sér. 20:234-265.

Carlquist S. 1981. Chance dispersal. American Scientist 69:509-516.

Césari SN, Parica CA, Remesal MB, Salani FM. 1998. First evidence of Pentoxylales in Antarctica. Cretaceous Research 19:733-743. DOI: 10.1006/cres.1998.0128.

Chaloner WG, Hemsley AR. 1992. A permineralized cycad seed from the Charlotte Islands, British Middle Jurassic of the Queen Columbia, Canada. Sonderdruck aus CFS-Courier Forschungsinstitut Senckenberg 147:233-239. 
757 Chamberlain CJ. 1906. The ovule and female gametophyte of Dioon. Botanical Gazette 42:321-358.

758 Cleal CJ, Rees PM. 2003. The Middle Jurassic flora from Stonesfield, Oxfordshire, UK. Palaeontology $759 \quad 46: 739-801$, Pls 15.

760 Cleal CJ, Thomas BA, Batten DJ, Collinson ME. 2001. Mesozoic and Tertiary palaeobotany of Great 761 Britain. Peterborough: Joint Nature Conservation Committee.

762 Combourieu N, Galtier J. 1985. Nouvelles observations sur Polypterospermum, Polylophospermum, 763 Colpospermum et Codonospermum, ovules de Ptéridospermales du Carbonifère supérieur 764 français. Palaeontographica Abteilung B:1-29.

765

766

767

768

769

770

771

772

773

774

775

776

777

778

Cope JCW, Ingham JK, Rawson PF. 1992. Atlas of palaeogeography and lithofacies. Geological Society of London.

Coulter JM, Chamberlain CJ. 1938. Morphology of gymnosperms. Chicago, USA: University of Chicago Press.

Dawson JW. 1872. Note on the fossil plant from Bristish Columbia, collected by Mr. James Richardson in 1872. Geological Survey of Canada Report of Progress:66-71.

Dehgan B, Yuen CKKH. 1983. Seed morphology in relation to dispersal, evolution, and propagation of Cycas L. Botanical Gazette 144:412-418. DOI: 10.2307/2474439.

Dower BL, Bateman RM, Stevenson DWM. 2004. Systematics, ontogeny, and phylogenetic implications of exceptional anatomically preserved cycadophyte leaves from Bearreraig Bay, Skye, Northwest Scotland. The Botanical Review 70:105-120.

Drinnan A, Chambers T. 1985. A reassessment of Taeniopteris daintreei from the Victorian Early Cretaceous: a member of the Pentoxylales and a significant Gondwanaland plant. Australian Journal of Botany 33:89-100. 
779

780

781

782

783

784

785

786

787

788

789

790

791

792

793

794

795

796

797

798

799

800

801

Dunn MT, Mapes G, Rothwell GW. 2002. On Paleozoic plants from marine strata: Hexaloba finisensia new genus and species, a trigonocarpalean ovule from the Virgillian (Upper Pennsylvanian: Gzhelian) Finis Shale of Texas. Journal of Paleontology 76:173-180.

Dunn MT, Rothwell GW, Mapes G. 2002. Additional observations on Rhynchosperma quinnii (Medullosaceae): a permineralized ovule from the Chesterian (Upper Mississippian) Fayetteville Formation of Arkansas. American Journal of Botany 89:1799-1808.

Escapa I, Cúneo R, Axsmith B. 2008. A new genus of the Cupressaceae (sensu lato) from the Jurassic of Patagonia: implications for conifer megasporangiate cone homologies. Review of Palaeobotany and Palynology 151:110-122. DOI: 10.1016/j.revpalbo.2008.03.002.

Escapa I, Leslie A. 2017. A new Cheirolepidiaceae (Coniferales) from the Early Jurassic of Patagonia (Argentina): Reconciling the records of impression and permineralized fossils. American Journal of Botany. DOI: 10.3732/ajb.1600321.

Farlow JO. 1987. Speculations about the diet and digestive physiology of herbivorous dinosaurs. Paleobiology 13:60-72.

Fleming TH, Lips KR. 1991. Angiosperm endozoochory: were pterosaurs Cretaceous seed dispersers? The American Naturalist 138:1058-1065.

Foster SA. 1986. On the adaptive value of large seeds for tropical moist forest trees: a review and synthesis. The Botanical Review 52:260-299. DOI: 10.1007/BF02860997.

Francis JE. 1983. The dominant conifer of the Jurassic Purbeck Formation, England. Palaeontology 26:277-294.

Friis EM, Pedersen Kaj Raunsgaard, Crane PR. 2013. New diversity among chlamydospermous seeds from the Early Cretaceous of Portugal and North America. International Journal of Plant Sciences 174:530-558. DOI: 10.1086/668250. 
802 Friis EM, Pedersen KR, Crane PR. 2014. Welwitschioid diversity in the Early Cretaceous: evidence from 803 fossil seeds with pollen from Portugal and eastern North America. Grana 53:175-196. DOI: 10.1080/00173134.2014.915980.

805

806

807

808

809

810

811

812

813

814

815

816

817

818

819

820

821

822

823

824

825

Galtier J, Phillips TL. 1999. The acetate peel technique. In: Jones TP, Rowe NP, eds. Fossil Plants and Spores: Modern Techniques. London, UK: The Geological Society, 67-70.

Garwood RJ, Dunlop JA. 2014. The walking dead: Blender as a tool for palaeontologists with a case study on extinct arachnids. Journal of Paleontology 88:735-746.

Gibson RN, Atkinson RJA, Gordon JDM. 2006. Oceanography and marine biology: an annual review. CRC Press.

Giddy C. 1974. Cycads of South Africa. Purnell.

Godefroit P, Cau A, Dong-Yu H, Escuillie F, Wenhao W, Dyke G. 2013. A Jurassic avialan dinosaur from China resolves the early phylogenetic history of birds. Nature 498:359-362.

Grimes ST, Brock F, Rickard D, Davies KL, Edwards D, Briggs DEG, Parkes RJ. 2001. Understanding fossilization: experimental pyritization of plants. Geology 29:123-126. DOI: 10.1130/00917613(2001)029<0123:UFEPOP>2.0.CO;2.

Grimes ST, Davies KL, Butler IB, Brock F, Edwards D, Rickard D, Briggs DEG, Parkes RJ. 2002. Fossil plants from the Eocene London Clay: the use of pyrite textures to determine the mechanism of pyritization. Journal of the Geological Society 159:493-501. DOI: 10.1144/0016-764901-176.

Gunn CR, Dennis JV. 1976. World guide to tropical drift seeds and fruits. Florida, USA: Krieger Publishing Company.

Guppy HB. 1906. Observations of a naturalist in the Pacific between 1896 and 1899. II. Plant dispersal. London, UK: Macmillan and Co.

Harris TM. 1964. The Yorkshire Jurassic flora. Volume II: Caytoniales, Cycadales, and Pteridosperms. London, UK: British Museum (Natural History). 
826 Harris TM, Millington W, Miller J. 1974. The Yorkshire Jurassic flora. Volume IV. London, UK: British $827 \quad$ Museum (Natural History).

828 Hass H, Rowe NP. 1999. Thin sections and wafering. In: Jones TP, Rowe NP, eds. Fossil Plants and Spores:

829 Modern Techniques. London, UK: The Geological Society, 76-82.

830 Heer O. 1876. Beiträge zur Jura-Flora Ostsibiriens und des Amurlandes. Mémoires de l'Academie 831 Imperiale des Sciences de Saint Pétersbourg. Ser. 7. 22:72-74.

832 Hickman-Lewis K, Garwood RJ, Brasier MD, Goral T, Jiang H, McLoughlin N, Wacey D. 2016.

833 Carbonaceous microstructures from sedimentary laminated chert within the 3.46 Ga Apex

834 Basalt, Chinaman Creek locality, Pilbara, Western Australia. Precambrian Research 278:161-178.

835 DOI: 10.1016/j.precamres.2016.03.013.

836 Hilton J, Cleal CJ. 2007. The relationship between Euramerican and Cathaysian tropical floras in the Late Palaeozoic: palaeobiogeographical and palaeogeographical implications. Earth-Science Reviews 85:85-116.

Johansen S, Hytteborn H. 2001. A contribution to the discussion of biota dispersal with drift ice and driftwood in the North Atlantic. Journal of Biogeography 28:105-115. DOI: 10.1046/j.1365-

Keddy P. 2007. Plants and vegetation: origins, processes, consequences. Cambridge, UK: Cambridge University Press.

Kendall MW. 1948. VII._On six species of Pagiophyllum from the Jurassic of Yorkshire and Southern England. Annals and Magazine of Natural History 1:73-108.

Kenig F, Hayes JM, Popp BN, Summons RE. 1994. Isotopic biogeochemistry of the Oxford Clay Formation (Jurassic), UK. Journal of the Geological Society 151:139-152. 26:625-646. 
850 Klavins SD, Taylor TN, Taylor EL. 2002. Anatomy of Umkomasia (Corystospermales) from the Triassic of $851 \quad$ Antarctica. American Journal of Botany 89:664-676.

852 van Konijnenburg-van Cittert JHA. 2008. The Jurassic fossil plant record of the UK area. Proceedings of

853

854

855

856

857

858

859

860

861

862

863

864

865

866

867

868

869

870

871

872

873 the Geologists Association 119:59-72.

van Konijnenburg-van Cittert JHA, Morgans HS. 1999. The Jurassic flora of Yorkshire. The Palaeontological Association.

Le Couls M, Hilton J, Guillocheau F, Morel N, Néraudeau D. 2016. Becklesia maulnyi nov. sp.: a new cycadean species from the Lower Oxfordian (Upper Jurassic) of Écommoy (Sarthe, NW France). Annales de Paléontologie 102:95-101. DOI: 10.1016/j.annpal.2016.05.005.

Limaye A. 2012. Drishti: a volume exploration and presentation tool. In: Proc. SPIE 8506, Developments in X-Ray Tomography VIII. San Diego, California, USA,. DOI: 10.1117/12.935640.

Liu X-Q, Li C-S, Wang Y-F. 2006. Plants of Leptostrobus Heer (Czekanowskiales) from the Early Cretaceous and Late Triassic of China, with discussion of the genus. Journal of Integrative Plant Biology 48:137-147. DOI: 10.1111/j.1744-7909.2006.00137.x.

Martill DM, Hudson JD. 1991. Fossils of the Oxford Clay. Palaeontological Association Field Guide to Fossils. Palaeontological Association.

Martill DM, Taylor MA, Duff KL, Riding JB, Bown PR. 1994. The trophic structure of the biota of the Peterborough Member, Oxford Clay Formation (Jurassic), UK. Journal of the Geological Society 151:173-194. DOI: 10.1144/gsjgs.151.1.0173.

Mohabey D. 2001. Dinosaur eggs and dung (faecal mass) from the Late Cretaceous of Central India; dietary implications: Geological Survey of India. Special Publication Series 64:605-615.

Molnar RE, Cifford HT. 2001. An ankylosaurian cololite from the Lower Cretaceous of Queensland, Australia. In: Carpenter K, ed. The Armored Dinosaurs. Indiana, USA: Indiana University Press, 399-412. 
874 Mustoe G. 2007. Coevolution of cycads and dinosaurs. The Cycad Newsletter 30:6-9.

875 Nagalingum NS, Marshall CR, Quental TB, Rai HS, Little DP, Mathews S. 2011. Recent synchronous

876 radiation of a living fossil. Science 334:796-799. DOI: 10.1126/science.1209926.

877 Ostrom JH. 1976. Archaeopteryx and the origin of birds. Biological Journal of the Linnean Society 8:91-

878 182. DOI: 10.1111/j.1095-8312.1976.tb00244.x.

879 Persoon CH. 1807. Synopsis plantarum, seu Enchiridium botanicum, complectens enumerationem

880 systematicam specierum hucusque cognitarum. Parisiis Lutetiorum: C.F. Cramerum.

881 Phillips T. 1980. Stratigraphic and geographic occurrences of permineralized coal-swamp plants-Upper

882 Carboniferous of North America and Europe. In: Dilcher DL, Taylor TN, eds. Biostratigraphy of

883 fossil plants: successional and palaeoecological analysis. Dowden, Hutchinson and Ross

$884 \quad$ Stroudsburg, PA, 25-92.

885 Porter H. 1863. On the occurrence of large quantities of fossil wood in the Oxford Clay, near

886 Peterborough. Quarterly Journal of the Geological Society 19:317-318.

887 Praeger RL. 1913. On the buoyancy of seeds of some Britannic plants. Proceedings of the Royal Dublin

$888 \quad$ Society 14:13-62.

889 Raiswell R. 1997. A geochemical framework for the application of stable sulphur isotopes to fossil

$890 \quad$ pyritization. Journal of the Geological Society 154:343-356.

891 Reymanówna M. 1973. The Jurassic flora from Grojec near Kraków in Poland. Part II - Caytoniales and anatomy of Caytonia. Acta Palaeontologica Sinica 14:46-87.

893

894

895

Rickard D, Luther GW. 1997. Kinetics of pyrite formation by the H2S oxidation of iron (II) monosulfide in aqueous solutions between 25 and $125^{\circ} \mathrm{C}$ : the rate equation. Geochimica et Cosmochimica Acta 61:115-134. DOI: 10.1016/S0016-7037(96)00321-3.

896 Ridley HN. 1930. The dispersal of plants throughout the world. Ashford, UK: Reeve \& Co Ltd.

897 Roth I. 1987. Stratification of a tropical forest as seen in dispersal types. Netherlands: Springer. 
898 Rothwell GW. 1986. Classifying the earliest gymnosperms. In: Spicer RA, Thomas BA, eds. Systematic and taxonomic approaches in palaeobotany. Oxford, UK: Oxford University Press, 137-162.

900

901

902

903

904

905

906

907

908

909

910

911

912

913

914

915

916

917

918

919

920

921

Rothwell GW, Mapes G, Hilton J, Hollingworth NT. 2007. Pollen cone anatomy of Classostrobus crossii sp. nov. (Cheirolepidiaceae). International Journal of Coal Geology 69:55-67.

Rothwell GW, Mapes G, Stockey RA, Hilton J. 2012. The seed cone Eathiestrobus gen. nov.: fossil evidence for a Jurassic origin of Pinaceae. American Journal of Botany 99:708-720.

Rothwell GW, Mapes G, Stockey RA, Hilton J. 2013. Diversity of ancient conifers: the Jurassic seed cone Bancroftiastrobus digitata gen. et sp. nov. (Coniferales). International Journal of Plant Sciences 174:937-946.

Rothwell GW, Serbet R. 1994. Lignophyte phylogeny and the evolution of spermatophytes: a numerical cladistic analysis. Systematic Botany 19:443-482. DOI: 10.2307/2419767.

Rothwell GW, Stockey RA. 2013. Evolution and phylogeny of gnetophytes: evidence from the anatomically preserved seedcone Protoephedrites eamesii gen. et sp. nov. and the seeds of several bennettitalean species. International Journal of Plant Sciences 174:511-529. DOI: $10.1086 / 668688$.

Rothwell GW, Stockey RA, Mapes G, Hilton J. 2011. Structure and relationships of the Jurassic conifer seed cone Hughmillerites juddii gen. et comb. nov.: implications for the origin and evolution of Cupressaceae. Review of Palaeobotany and Palynology 164:45-59.

Rothwell GW, Stockey RA, Stevenson DW. 2017.Cycas-like seeds in the Bajocian Stage of the Middle Jurassic. Abstract ID: 358. Botany 2017 - Botanical Crossroads, Fort Worth, Texas. Available at http://www.botanyconference.org/engine/search/index.php?func=detail\&aid=358

Sahni B. 1948. The Pentoxyleae: A New Group of Jurassic Gymnosperms from the Rajmahal Hills of India. Botanical Gazette 110:47-80. DOI: 10.2307/2472557.

Saporta GD. 1875. Paleontologie francaise 2em Serie - Vegetaux - Plantes Jurassiques. Paris, France. 
922 Serbet R, Rothwell GW. 1995. Functional morphology and homologies of gymnospermous ovules:

923 evidence from a new species of Stephanospermum (Medullosales). Canadian Journal of Botany

$924 \quad 73: 650-661$.

925 Seward AC. 1904. Catalogue of the Mesozoic plants in the Department of Geology, British Museum

926 (Natural History). Part 4. The Jurassic flora. London: Printed by order of the Trustees.

927 Seward AC. 1913. A petrified Williamsonia from Scotland. Philosophical Transactions of the Royal Society

928 of London B: Biological Sciences 203:101-126. DOI: 10.1098/rstb.1913.0003.

929 Seward AC. 1917. Fossil plants, a text-book for students of botany and geology, Volume 3. Cambridge, $930 \quad$ England: Cambridge University Press.

931 Seward AC, Bancroft N. 1913. XXXII._Jurassic plants from Cromarty and Sutherland, Scotland.

932 Transactions of the Royal Society of Edinburgh 48:867-888.

933 Seward AC, Gowan J. 1900. The Maidenhair tree (Ginkgo biloba, L.): with plates VIII-X. Annals of Botany $934 \quad 14: 109-154$.

Sharma BD. 1970. On the structure of the seeds of Williamsonia collected from the Middle Jurassic rocks of Amarjola in the Rajmahal Hills, India. Annals of Botany 34:1071-1077.

937 Sharma BD. 1980. The Micropyle in Williamsonia Carr. (Bennettitales). Annals of Botany 45:191-193.

Sharma BD. 2001. Misinterpretations about the "Pentoxyleae" - a Mesozoic gymnospermous group of plants. Palaeobotanist 50:255-265.

Singh H. 1978. Embryology of gymnosperms. Stuttgart, Germany: Schweizerbart Science Publishers.

Skyring GW. 1987. Sulfate reduction in coastal ecosystems. Geomicrobiology Journal 5:295-374. DOI: $10.1080 / 01490458709385974$.

Spencer ART, Hilton J, Sutton MD. 2013. Combined methodologies for three-dimensional reconstruction of fossil plants preserved in siderite nodules: Stephanospermum braidwoodensis nov. sp. 
947 Spencer ART, Mapes G, Bateman RM, Hilton J, Rothwell GW. 2015. Middle Jurassic evidence for the origin of Cupressaceae: a paleobotanical context for the roles of regulatory genetics and development in the evolution of conifer seed cones. American Journal of Botany 102:942-961. DOI: 10.3732/ajb.1500121.

Spencer ART, Wang S-J, Dunn MT, Hilton J. 2013. Species of the medullosan ovule Stephanospermum from the Lopingian (late Permian) floras of China. Journal of Asian Earth Sciences 76:59-69. DOI:

Sporne KR. 1971. The morphology of gymnosperms: the structure and evolution of primitive seed-plants. London: Hutchinson.

Srivastava BP. 1935. On silicified plant remains from the Rajmahal series of India. Proceedings of teh 22nd Indian Science Congress, Calcutta:285.

Srivastava BP. 1937. Studies on some silicified plant plant remains from the Rajmahal series. Proceedings of the 24th Indian Congress, Hyderbad-Deccan:273-274.

Srivastava BP. 1946. Siliciifed plant remains from the Rajmahal Series of India. Proceedings of the National Academy of Sciences India 15:185-211.

962

963

Steart DC, Spencer ART, Garwood RJ, Hilton J, Munt MC, Needham J, Kenrick P. 2014. X-ray synchrotron microtomography of a silicified Jurassic Cheirolepidiaceae (Conifer) cone: histology and morphology of Pararaucaria collinsonae sp. nov. PeerJ:2:e624.

Stevenson DW. 1990. Morphology and systematics of the Cycadales. Memoirs of the New York Botanical Garden 57:8-55.

Stockey RA. 1994. Mesozoic Araucariaceae: morphology and systematic relationships. Journal of Plant Research 107:493-502. 
969 Stockey RA, Rothwell GW. 2003. Anatomically preserved Williamsonia (Williamsoniaceae): evidence for

970 Bennettitalean reproduction in the Late Cretaceous of Western North America. International $971 \quad$ Journal of Plant Sciences 164:251-262.

972 Stokes WL. 1964. Fossilized stomach contents of a sauropod dinosaur. Science 143:576-577. DOI:

973 10.1126/science.143.3606.576.

974 Stopes MC. 1905. On the double nature of the cycadean integument. Annals of Botany 19:561-566.

975 Sutton MD, Garwood RJ, Siveter DJ, Siveter DJ. 2012. SPIERS and VAXML: A software toolkit for 976 tomographic visualisation and a format for virtual specimen interchange. Palaeontologia

977 Electronica 15.2.4T.

978

Taylor TN. 1966. Paleozoic seed studies: on the genus Hexapterospermum. American Journal of Botany

979 53:185-192.

980

Taylor TN, Eggert DA. 1967. Petrified plants from the Upper Mississippian of North America. I: the seed 981 Rhynchosperma gen. nov. American Journal of Botany 55:306-313.

Taylor TN, Fueyo GMD, Taylor EL. 1994. Permineralized seed fern cupules from the Triassic of Antarctica: implications for cupule and carpel evolution. American Journal of Botany 81:666-677. DOI:

985

Taylor TN, Taylor EL, Krings M. 2009. Paleobotany: the biology and evolution of fossil plants. Amsterdam: Elsevier and Academic Press.

987

Tibbs SL, Briggs DEG, PrössI KF. 2003. Pyritisation of plant microfossils from the Devonian Hunsrück Slate 988 of Germany. Paläontologische Zeitschrift 77:241-246. DOI: 10.1007/BF03004571.

Tiffney BH. 2004. Vertebrate dispersal of seed plants through time. Annual Review of Ecology, Evolution, 990 and Systematics 35:1-29. DOI: 10.1146/annurev.ecolsys.34.011802.132535. 
991 Wang X, Zhou Z. 2003. A new pterosaur (Pterodactyloidea, Tapejaridae) from the Early Cretaceous 992 Jiufotang Formation of western Liaoning, China and its implications for biostratigraphy. Chinese 993 Science Bulletin 48:16-23.

994

995

996

997

998

999

1000

1001

1002

1003

1004

1005

1006

1007

1008

1009

1010

1011

1012

Weigelt J. 1930. Über die vermutliche Nahrung von Protorosaurus und über einen körperlich erhaltenen Fruchtstand von Archaeopodocarpus germanicus aut. Leopoldina 6:269-280.

Wellnhofer P. 1991. The skull of Tapejara wellnhoferi Kellner (Reptilia, Pterosauria) from the Lower Cretaceous Santana Formation of the Araripe Basin, Northeastern Brazil. Mitteilungen der Bayerischen Staatssammlung für Paläontologie und Historische Geologie 31:89-106.

Werker E. 1997. Seed anatomy. Berlin, Germany: Schweizerbart Science Publishers.

Westoby M, Jurado E, Leishman M. 1992. Comparative evolutionary ecology of seed size. Trends in Ecology \& Evolution 7:368-372. DOI: 10.1016/0169-5347(92)90006-W.

Wignall PB, Pickering KT. 1993. Palaeoecology and sedimentology across a Jurassic fault scarp, NE Scotland. Journal of the Geological Society 150:323-340. DOI: 10.1144/gsjgs.150.2.0323.

Wilby PR, Hudson JD, Clements RG, Hollingworth NTJ. 2004. Taphonomy and origin of an accumulate of soft-bodied cephalopods in the Oxford Clay Formation (Jurassic, England). Palaeontology 47:1159-1180. DOI: 10.1111/j.0031-0239.2004.00405.x.

Zhou Z. 2004. The origin and early evolution of birds: discoveries, disputes, and perspectives from fossil evidence. Naturwissenschaften 91:455-471. DOI: 10.1007/s00114-004-0570-4.

Zhou Z, Zhang F. 2002. A long-tailed, seed-eating bird from the Early Cretaceous of China. Nature 418:405-409. DOI: 10.1038/nature00930. 


\section{Figure Legends}

1015

1016

1017

1018

1019

1020

1021

1022

1023

1024

1025

1026

1027

1028

1029

1030

1031

1032

1033

1034

1035

Figure 1. UK Lagerstätten locations and temporal ranges (Ma) in the Jurassic Period. Time range chart showing depositional periods for the five UK Lagerstätten.

Figure 2. Stratigraphic placement and location map. A) Stratigraphic summary showing the position of the ammonite $Q$. lamberti and $Q$. mariae biozones and their subzones, which correlate to the latest Callovian Stage and early Oxfordian Stage of the Jurassic, and the middle Oxford Clay Fm deposits; B) Map showing onshore exposures of the Oxford Clay Fm and the position of fossil recovery localities. Diagram based on Martill and Hudson (1991).

Figure 3. Photographs of specimen BU 5265 prior to fracturing from pyritic decay. A) Side of ovule, with pointed apex and flattened base, showing longitudinal ribs which merge towards the apex; B) Side view rotated 90 degrees side from A, showing 'bored' hole (arrow), and bilateral symmetry of the ribs and base; C) Basal view showing 12 ribs and the attachment scar; D) Oblique apex view showing the ribs tapering to a point, 'bored' hole indicated by arrow. Scale bar $=10 \mathrm{~mm}$.

\section{Figure 4. Photographs of specimen BU 5266 prior to serial wafering and peeling. A) Side view of ovule} showing decayed outer surface with eroded ribs; B) View of heavily decayed apex showing the rounded 12 ribbed nature of the ovule; C) Oblique side view showing ribbed outer surface, with zones of decay exposing inner integument, red staining on the base shows attachment scar; D) Basal view, note the four relatively intact ribs seen towards the image top, and the attachment scar denoted by the red staining. Scale bar $=10 \mathrm{~mm}$. 
1036

1037 Figure 5. Diagram showing position of cuts, wafers and peels taken from specimen BU 5266. Red lines = 1038 saw cuts; $p=$ peel; $w$ = wafer.

1039

Figure 6. Virtual $25 \mu \mathrm{m}$ thin-sections showing gross morphology and anatomy of BU 5265.1 created from the Drishti volume rendered three-dimensional model. Each figure shows (A, D) full SRXMT data in grayscale with enhanced brightness and contrast; $(B, E)$ false-colour image showing only the high density pyritic material; and (,$F$ ) the medium density organic and carbonate-rich materials. $\mathrm{A}-\mathrm{C})$ Longitudinal section through ovule. Showing at the apex a nucellar beak $(\mathrm{Nb})$ that protrudes from the top of the nucellar membrane $(\mathrm{N})$ within a defined micropyle $(\mathrm{Mi})$ region. Several major layers of the integument $\left(\operatorname{Int} t^{\circ}=\right.$ outer; $\ln t^{m}=$ middle) are seen; $\left.D-F\right)$ Cross-section across ovule, approx. $1 / 4$ distance from base to apex, line of section as marked on A-C. All scale bars $=1 \mathrm{~mm}$.

1048

Figure 7. Gross morphology and internal feature distribution of BU 5266 viewed as wafers and virtual thick-sections. Wafers A \& C viewed in reflected light photographed using a Zeiss Tessovar, and virtual thick-sections B \& C created from the SRXMT data in the Drishti volume rendered. A, B) cross-sectional

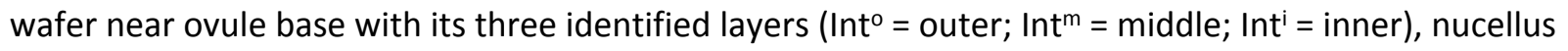
$(\mathrm{N})$, and megagametophyte (Mg); B) longitudinal wafer near ovule centre with its three identified layers $\left(\operatorname{Int}{ }^{\circ}=\right.$ outer; $\operatorname{lnt} t^{m}=$ middle; $\operatorname{lnt} t^{i}=$ inner $)$, nucellus $(\mathrm{N})$, megaspore membrane $(\mathrm{Mm})$, and megagametophyte (Mg). Slides: A, B = BU 5266.37 BH.2.13.TS; C, D = BU 5266.3. All scale bars $=2 \mathrm{~mm}$.

Figure 8. Three-dimensional isosurface-based false-coloured reconstruction model, BU 5265.1. (A, B) and BU $5265.2(C-D)$, showing gross morphology of the ovule. A) Longitudinal view showing ovule with partly remaining integument. The ribbed outer integument $\left(\operatorname{Int} t^{\circ}\right)$ can be seen, with furrows containing 
1060 Oxford Clay $(\mathrm{Cl})$, overlying the middle and inner integumentary layers (Int $\left.{ }^{\mathrm{M}+\mathrm{I}}\right)$. The cavity formed by the 1061 integument is digitally filled (Int. Cav.). Note the micropyle protruding from the apex (Mi); B) Basal view 1062 showing the heavily ribbed nature of the integument with attached Oxford Clay; C) Longitudinal view of

1063

1064

1065

1066

1067

1068

1069

1070

1071

1072

1073

1074

1075

1076

1077

1078

1079

1080

1081

1082

1083

a basal integument section showing the ribs terminating at towards the attachment scar; D) Longitudinal view 90 degrees from $\mathrm{C}$ showing the flattened nature of the base and multi-layered construction of the integument; E) View of the integument section from the apex showing the middle and inner integument packing the central portions of the ribs. Scale bar $=10 \mathrm{~mm}$. Animations of these reconstructions can be seen in Videos S1 and S2.

Figure 9. Virtual $25 \mu \mathrm{m}$ thin-sections showing gross morphology and anatomy of BU 5265.1 created from the Drishti volume rendered three-dimensional model. A, D, G) full SRMT data in grayscale with enhanced brightness and contrast; $B, E, H$ ) false-colour image showing only the high density pyritic material; and C, F, I) the medium density organic and carbonate rich materials. A, B, C) Enlarged longitudinal view of the apex seen in Fig. $6 \mathrm{~A}-\mathrm{C}$. Showing a nucellar beak $(\mathrm{Nb})$ that protrudes from the top of a possible small pollen chamber $(\mathrm{Pc})$, the nucellar membrane $(\mathrm{N})$, and the micropyle $(\mathrm{Mi})$ region; C-F) Longitudinal section of integument, through the maximum width of a rib, line of section as marked on Fig. 6D-F. Showing the three identified layers of the integument $\left(\operatorname{Int} t^{\circ}=\right.$ outer; $\operatorname{Int} t^{m}=$ middle; $\operatorname{Int}^{i}=$ inner), $\mathrm{F}$ also shows the location of the nucellus (N); $\mathrm{G}-\mathrm{I}$ ) Enlarged cross-sectional view of integument, as marked on Fig. 6D-F. Showing two ribs, with Oxford Clay infill in the rib furrow, and the integument with its three identified layers $\left(\ln t^{o}=\right.$ outer; $\ln t^{m}=$ middle; $I n t^{i}=$ inner $)$. All scale bars $=1 \mathrm{~mm}$.

Figure 10. Physical wafer and peel sections of BU 5266 showing state of preservation and anatomy. Wafers (reflective light) and peels (transmitted) light were photographed using a Zeiss Tessovar. A) Longitudinal wafer showing the extensive pyrite and pyritic decay of the integument with patches of 
1084 preserved middle integument (Int) and small portions of nucellus (N). Slide BU 5266.3. B) Longitudinal 1085 peel showing integument with its thin inner layers $\left(\operatorname{Int} \mathrm{t}^{\mathrm{i}}\right)$ and middle layer $\left(\ln \mathrm{t}^{\mathrm{m}}\right)$. The external surface of 1086 the integument is degraded (left of image). Slide BU 5266.12. C) Enlarged view from A showing the preserved middle integument cells. Slide BU 5266.3 D) Longitudinal wafer showing micropyle (Mi) at the middle top of the ovule, the thin nucellus $(\mathrm{N})$ closely following integument, and the megaspore membrane $(\mathrm{Mm})$ and megagametophyte $(\mathrm{Mg})$ within the integumentary cavity. Slide BU 5266.3. E, F) High magnification of wafer showing the construction of the nucellus (N). Slide BU 5266.2. G) High magnification of preserved cells from within the megaspore membrane interpreted as megagametophyte tissue (Mg). Slide BU 5266.37. Scale bars: $A, D=1 \mathrm{~mm}, E=0.5 \mathrm{~mm}$, all others $0.25 \mathrm{~mm}$.

Figure 11. Three-dimensional isosurface-based false-coloured reconstruction model of BU 5265.1 showing a digitally filled integumentary cavity cast. A) Longitudinal view looking along the central apex infilled internal integumentary groove; B) apex view of the infilled internal integumentary groove with the micropyle protruding (Mi); C) longitudinal view showing the infilled internal integumentary groove with central micropyle in profile. Scale bars $=5 \mathrm{~mm}$.

Figure 12. Three-dimensional isosurface-based false-coloured reconstruction model of BU 5265.1 showing internal ovule morphology. A) Ovule, with Oxford Clay and digitally filled integumentary cavity removed, showing the multi-layered integument $\left(\operatorname{Int}{ }^{O}\right.$ and $\left.\operatorname{Int} \mathrm{t}^{\mathrm{M}+1}\right)$ surrounding a large nucellus $(\mathrm{N})$ with micropyle channel at apex (digitally infilled; Mi); B) Longitudinal section through the middle of $\mathrm{A}$. The nucellus, which has deteriorated towards the back of the view, possesses a small nucellar beak at is apex $(\mathrm{Nb})$, that protrudes into the micropyle channel (digitally infilled; Mi); C) Nucellus ( $\mathrm{N}$ ) and digitally infilled micropyle (Mi), shown without surrounding integument; D) Enlarged apex view of C, with micropyle 
1108 channel (Mi) shown as semi-transparent, and nucellus beak (Nb) within. Dashed line indicates the

1109 boundary between the digitally infilled micropyle and the nucellar beak; E) Longitudinal section through

1110 the apex of $\mathrm{D}$. Showing the nucellus $(\mathrm{N})$, with small pollen chamber $(\mathrm{Pc})$ that resided below the nucellar

1111 beak (Nb). The digitally infilled micropyle (Mi) is shown.; F) Cross-section through $\mathrm{E}$, showing

1112 relationship between nucellus $(\mathrm{N})$, the nucellar beak $(\mathrm{Nb})$, and the micropyle (Mi). Scale bars: $\mathrm{A}, \mathrm{B}=5$

$1113 \mathrm{~mm} ; \mathrm{C}=1 \mathrm{~cm} ; \mathrm{D}-\mathrm{F}=1 \mathrm{~mm}$.

1114

1115 Figure 13. Original pen and ink drawings of Cycadeospermum ovules from Saporta (1875; 1891). A) C.

1116 schlumbergeri from Plate CXVII Fig. 11 of Saporta (1875) showing ovule looking down on apex with

1117 ribbed integument and lateral opening (arrow); B) C. schlumbergeri from Plate CXVII Fig. 12 of Saporta

1118 (1875) showing longitudinal view of ovule with ribbed integument, pointed apex and flattened base; C)

1119 C. berlieri from Plate CCXCVIII Fig. 3 of Saporta (1891) showing longitudinal view of ovule with ribbed

1120 integument; D) Smaller specimen of C. berlieri from Plate CCXCVIII Fig. 4 of Saporta (1891) showing

1121 longitudinal view of ovule with ribbed integument; E) C. choffati from Plate CCXCVIII Fig. 5 of Saporta

1122 (1891) showing longitudinal view of ovule with ribbed integument, with attachment point at base. Scale

1123 bar = ca. $1 \mathrm{~cm}$ (based on information given by Saporta in text).

1124

1125 Figure 14. Fossilization phase diagram. Illustrating the qualitative changes at varying depths/zones $(\mathrm{A})$ in

1126 dissolved iron and sulphide (B) and how these changes affect the saturation state between iron and

1127 carbonate during microbial diagenesis $(C)$, as well as showing the related different styles of fossilization

1128 (D). E) An SRXMT longitudinal section of BU 5265.1 showing the two phases of mineralization. See Figure

1129 S1 A-D for more SRXMT section images. Phase data based on Raiswell (1997). 
Supplementary Information

1131

1132

1133

1134

1135

1136

1137

1138

1139

1140

1141

1142

1143

1144

1145

1146

1147

1148

1149

1150

1151

1152

1153

Text to be removed before publication.

Most SI information can be access on Zenodo with the DOI 10.5281/zenodo.61841. This is not currently

publicly available; however, reviewers may access these files by using the following unique and

anonymous link:

https://zenodo.org/record/61841?token=eyJhbGciOiJIUzI1NilsImV4cCI6MTUxNDY3MTE5OSwiaWF0ljox

NDkxMzAwNjg5fQ.eyJkYXRhljp7InJIY2Ikljo2MTg0MX0sImlkljoxMjQsInJuZCI6ImZmMTcyN2MOIn0.QJFKH

NqwwY834Dp2qKpIGwWXS0O2OMq5YI0xicZQVDs

Additional new SI, containing the original XMT and SRXMT tomographic data has now been uploaded to

Zenodo. Each, due to the dataset file size, has been given a unique doi (see below) which will become

active and allow open-source public access once publication of the paper has occurred.

Reviewer/editors may request access to these files if required.

Video S1. Animation of the isosurface-based false-coloured three-dimensional model for specimen BU 5265.1. Full 360-degree rotation on the $x$-axis followed by the $y$-axis. Scale bar $=0.5 \mathrm{~cm}$ [MOV format 13MB, AVI format 44MB; 1920x1080 px; 1:04 min] DOI: https://doi.org/10.5281/zenodo.61841

Video S2. Animation of the isosurface-based false-coloured three-dimensional model for specimen BU 5265.2. Full 360-degree rotation on the $x$-axis followed by the $y$-axis. Scale bar $=0.5 \mathrm{~cm}$. [MOV format 20MB, AVI format 44MB; 1920x1080 px; 1:04 min] DOI: https://doi.org/10.5281/zenodo.61841

Video S3. Tomographic data set showing raw X-ray contrast data as produced by the I12 JEEP beamline at the Diamond Light Source for specimen BU 5265.1. Scale bar $=0.25 \mathrm{~mm}$. [MOV format 42MB, AVI format 53MB; 1004x1002 px; 1:15 min] DOI: https://doi.org/10.5281/zenodo.61841 
1155

1156

1157

1158

1159

1160

1161

1162

1163

1164

1165

1166

1167

1168

1169

1170

1171

1172

1173

1174

1175

1176

1177

Model S1. Zenodo hosted three-dimensional model file of BU 5265.1 isosurface-based false-coloured reconstruction. This model is saved as a ZIP compressed VAXML datasets. VAXML uses one or more STL files to define the geometry of objects that comprise the dataset, together with one VAXML file that provides metadata on the dataset as a whole, and specifies how the STL/PLY files are to be put together. Additionally, a native SPV file has been included for direct viewing in SPIERSview. We therefore recommend the free SPIERS software to view this model format (http://spiers-software.org/). Additional information on the VAXML format can be found here: http://spiers-software.org/VAXML.htm. [ZIP/VAXML format 198.4 MB; SPV format 4MB] DOI: https://doi.org/10.5281/zenodo.61841

Model S2. Zenodo hosted three-dimensional model file of BU 5265.2 isosurface-based false-coloured reconstruction. This model is saved as a ZIP compressed VAXML datasets. VAXML uses one or more STL files to define the geometry of objects that comprise the dataset, together with one VAXML file that provides metadata on the dataset as a whole, and specifies how the STL/PLY files are to be put together. Additionally, a native SPV file has been included for direct viewing in SPIERSview. We therefore recommend the free SPIERS software to view this model format (http://spiers-software.org/). Additional information on the VAXML format can be found here: http://spiers-software.org/VAXML.htm. [ZIP/VAXML format 173.6 MB; SPV format 3MB] DOI: https://doi.org/10.5281/zenodo.61841

Figure S1. High resolution volume rendered images from Drishti showing the anatomy of BU 5265 and BU 5266. A) 16 longitudinal virtual thin-sections through BU 5265.1 at $500 \mu \mathrm{m}$ spacing; B) 40 transverse virtual thin-sections through BU 5265.1 at $500 \mu \mathrm{m}$ spacing; C) 28 transverse virtual thin-sections through BU 5265.2 at $500 \mu \mathrm{m}$ spacing; D) 38 transverse virtual thin-sections through BU 5265.3 at 500 $\mu \mathrm{m}$ spacing; E) Reconstruction of BU 5265.1 showing longitudinal view of whole specimen fragment; F) 
1178 Reconstruction of thick section slide BU 52665.30, a: oblique view of slide looking from the outer surface

1179 toward the inside of the ovule near the apex, b: oblique view of the slide looking out from the inside of

1180 the ovule, $c$ : top-down view of the slide looking towards the ovule base, $d$ : 3D section virtually cut from

1181 the slide showing the orientation of integumentary layers. G) Reconstruction of thick section slide BU

118252665.1 , a: view of slide looking from the inner surface toward the outside of the ovule, b: view of the

1183 slide looking towards the inside of the ovule, c: longitudinal section through the virtual slide. H)

1184 Reconstruction of thick section slide BU 52665.38, a: outer anatomy seen looking to the ovule centre

1185 from the base, $\mathrm{b}$ : inner anatomy seen looking from the ovule centre towards the base, c: longitudinal

1186 section through the virtual slide. I) Reconstruction of thick section slide BU 52665.3, a: view of slide

1187 looking towards the ovule centre, b: view of slide looking from ovule centre towards the external

1188 surface, c: longitudinal section through the virtual slide. J) Reconstruction of thick section slide BU

118952665.37 , a: view of slide looking away from the ovule centre, b: view of slide looking towards the ovule

1190 centre, c: longitudinal section through the virtual slide. Notes: A-D) These images show the two phases

1191 of mineralization which have preserved the ovule anatomy, blue = carbonate (calcite), yellow = pyrite,

1192 each having differing $\mathrm{x}$-ray attenuation characteristics; $\mathrm{E}-\mathrm{J}$ ) These images highlight just the pyrite within

1193 the ovule, in particular that which infills the cells. Scale bars sizes are indicated on the figure. [PNG

1194 format 76MB] DOI: https://doi.org/10.5281/zenodo.61841

1195

1196

Dataset S1. XMT 8-bit BMP tomographic dataset of BU5265.1. The dataset consists of 754 8-bit bitmap

images compressed as a ZIP archive. Image brightness/contrast optimized and despeckling applied. Note

249 MB] DOI: https://doi.org/10.5281/zenodo.824099 
1201

1202

1203

1204

1205

1206

1207

1208

1209

1210

1211

1212

1213

1214

1215

1216

1217

1218

1219

1220

1221

1222

1223

Dataset S2. XMT 8-bit BMP tomographic dataset of BU5265.2. The dataset consists of 724 8-bit bitmap images compressed as a ZIP archive. Image brightness/contrast optimized and despeckling applied. Note that images from the tomographic have been cropped to include only the specimen. [ZIP/BMP format 635 MB] DOI: https://doi.org/10.5281/zenodo.824103

Dataset S3. SRXMT 8-bit BMP tomographic dataset of BU5265.1. The dataset consists of 2180 8-bit bitmap images compressed as a ZIP archive. Image brightness/contrast optimized and despeckling applied. Note that images from the tomographic stack beginning and end, without specimen data present, have not been included. [ZIP/BMP format 23.1 GB] DOI:

https://doi.org/10.5281/zenodo.824029

Dataset S4. SRXMT 8-bit BMP tomographic dataset of BU5265.2. The dataset consists of 1200 8-bit bitmap images compressed as a ZIP archive. Image brightness/contrast optimized and despeckling applied. Note that images from the tomographic stack beginning and end, without specimen data present, have not been included. [ZIP/BMP format $10.6 \mathrm{~GB}] \mathrm{DOI}$ :

https://doi.org/10.5281/zenodo.824047

Dataset S5. SRXMT 8-bit BMP tomographic dataset of BU 5265.3. The dataset consists of 1200 8-bit bitmap images compressed as a ZIP archive. Image brightness/contrast optimized and despeckling applied. Note that images from the tomographic stack beginning and end, without specimen data present, have not been included. [ZIP/BMP format 10.3 GB] DOI:

https://doi.org/10.5281/zenodo.824051 
1224 Dataset S6. SRXMT 8-bit BMP tomographic dataset of slide BU 5266.3. The dataset consists of 300 8-bit

1225 bitmap images compressed as a ZIP archive. Image brightness/contrast optimized and despeckling

1226 applied. Note that images from the tomographic stack beginning and end, without specimen

1227 data present, have not been included. [ZIP/BMP format $3.3 \mathrm{~GB}$ ] DOI:

1228 https://doi.org/10.5281/zenodo.824073

1229

1230

Dataset S7. SRXMT 8-bit BMP tomographic dataset of slide BU 5266.30. The dataset consists of 701 8-bit bitmap images compressed as a ZIP archive. Image brightness/contrast optimized and despeckling applied. Note that images from the tomographic stack beginning and end, without specimen data present, have not been included. [ZIP/BMP format 7.6 GB] DOI: https://doi.org/10.5281/zenodo.824079

1235

Dataset S8. SRXMT 8-bit BMP tomographic dataset of slide BU 5266.37. The dataset consists of 400 8-bit bitmap images compressed as a ZIP archive. Image brightness/contrast optimized and despeckling applied. Note that images from the tomographic stack beginning and end, without specimen data present, have not been included. [ZIP/BMP format 3.9 GB] DOI: https://doi.org/10.5281/zenodo.824085

Dataset S9. SRXMT 8-bit BMP tomographic dataset of slide BU 5266.38. The dataset consists of 351 8-bit bitmap images compressed as a ZIP archive. Image brightness/contrast optimized and despeckling applied. Note that images from the tomographic stack beginning and end, without specimen data present, have not been included. [ZIP/BMP format 3.4 GB] DOI: https://doi.org/10.5281/zenodo.824089 
1248 Dataset S10. SRXMT 8-bit BMP tomographic dataset of slide BU 5266.39. The dataset consists of 421 8-

1249 bit bitmap images compressed as a ZIP archive. Image brightness/contrast optimized and despeckling

1250 applied. Note that images from the tomographic stack beginning and end, without specimen

1251 data present, have not been included. [ZIP/BMP format $4.0 \mathrm{~GB}$ ] DOI:

1252 https://doi.org/10.5281/zenodo.824091

1253 


\section{Figure 1}

UK lagerstätten locations and temporal ranges in the Jurassic.

Time range chart showing depositional periods for the five UK lagerstätten. 

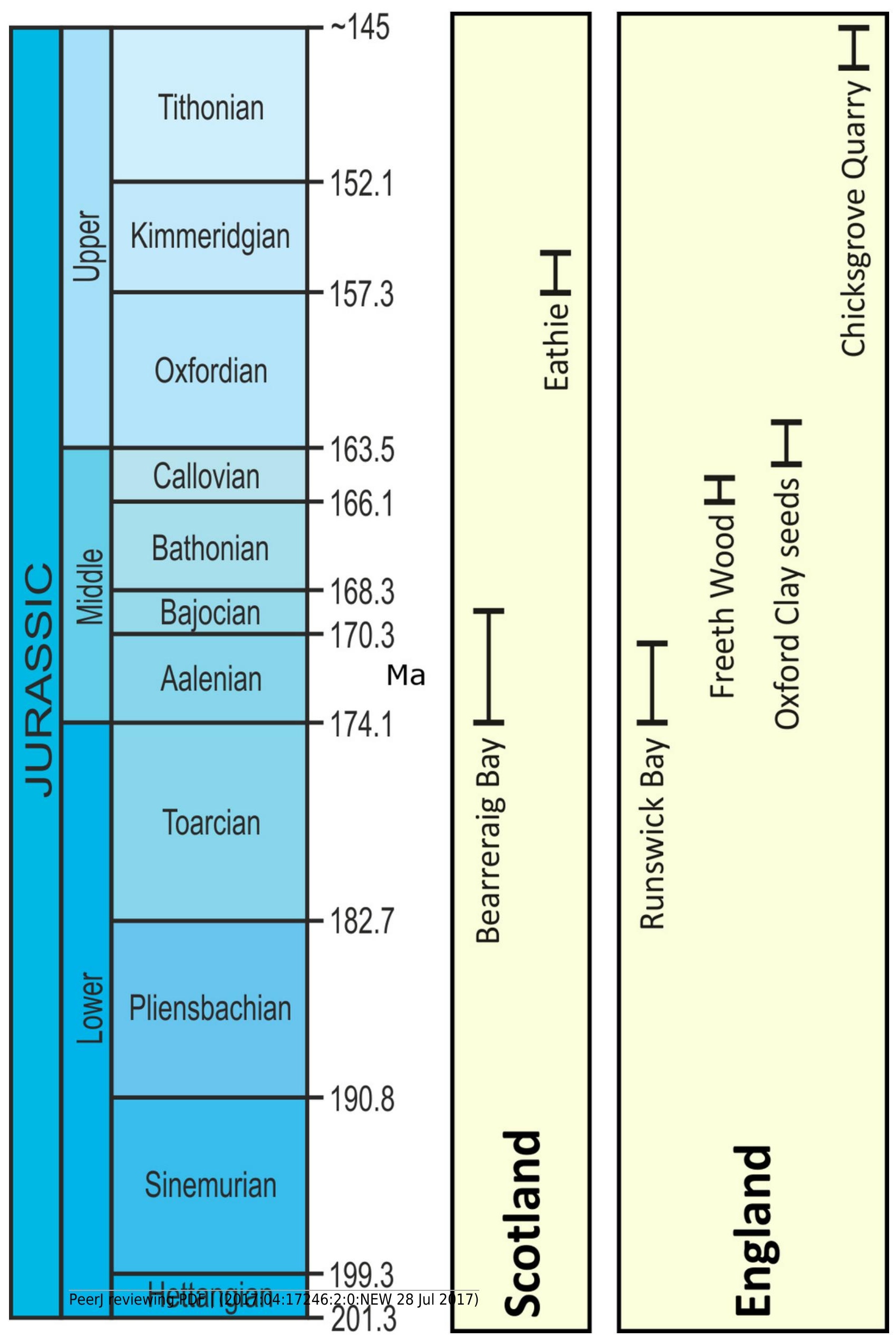
Figure 2

Stratigraphic placement and location map.

A) Stratigraphic summary showing the position of the ammonite Q. lamberti and Q. mariae biozones and their subzones, which correlate to the latest Callovian Stage and early Oxfordian Stage of the Jurassic, and the middle Oxford Clay Fm deposits; B) Map showing onshore exposures of the Oxford Clay Fm and the position of fossil recovery localities.

Diagram based on Martill and Hudson (1991).

A

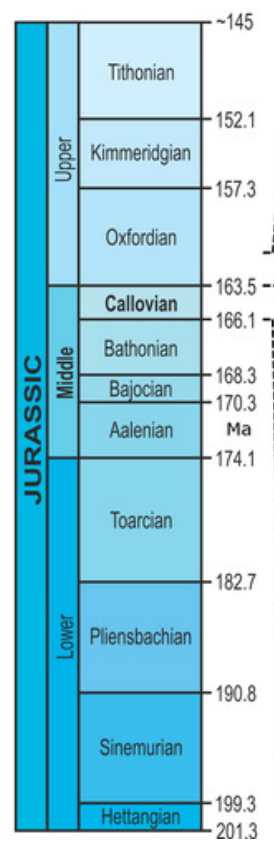

B

\begin{tabular}{|c|c|c|}
\hline Lithostratigraphy & Ammonite biozone & Ammonite subzone \\
\hline \multirow{5}{*}{$\begin{array}{l}\text { Weymouth } \\
\text { Member }\end{array}$} & \multirow{3}{*}{ Cardioceras cordatum } & Cardioceras cordatum \\
\hline & & Cardioceras costicarda \\
\hline & & Cardioceras bukowskii \\
\hline & \multirow{2}{*}{ Quenstedtoceras mariae } & Cardioceras praecordatum \\
\hline & & Cardioceras scarburgense \\
\hline \multirow{4}{*}{$\begin{array}{l}\text { Stewartby } \\
\text { Member }\end{array}$} & \multirow{2}{*}{ Quenstedtoceras lambert } & Quenstedtoceras lamberti \\
\hline & & Quenstedtoceras henrici \\
\hline & & Kosmoceras spinosum \\
\hline & Pelloceras athleta & Kosmoceras proniae \\
\hline \multirow{6}{*}{ 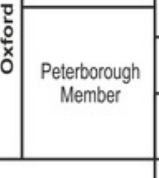 } & & Kosmoceras phaeinum \\
\hline & Evymnoceras coronatum & Kosmoceras grossouvrei \\
\hline & Erymnoceras coronatum & Kosmoceras obductum \\
\hline & Kosmoceras jason & Kosmoceras jason \\
\hline & & Kosmoceras medea \\
\hline & Sigalloceras callovie & Sigaloceras enodatum \\
\hline \multirow{3}{*}{$\begin{array}{l}\text { Kellaways Sand } \\
\text { Formation }\end{array}$} & & Sigaloceras calloviense \\
\hline & \multirow{3}{*}{ Proplanulites koenigi } & Kepplerites galliaei \\
\hline & & Kepplentes curtilobus \\
\hline $\begin{array}{l}\text { Kellaways Clay } \\
\text { Formation }\end{array}$ & & Kepplentes gowerianus \\
\hline & \multirow{2}{*}{ Macrocephalites herveyi } & Macrocephalites kamptus \\
\hline $\begin{array}{l}\text { Abbotsbury } \\
\text { Cornbrash Formati }\end{array}$ & & Macrocephalites terebratus \\
\hline
\end{tabular}

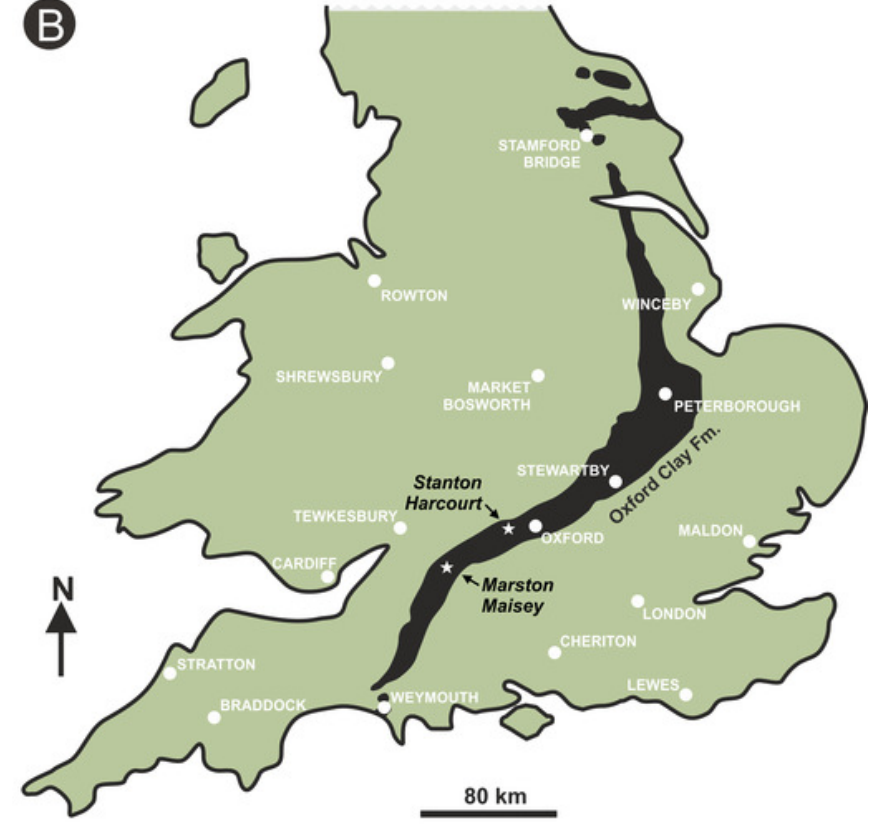




\section{Figure 3}

Photographs of specimen BU 5265 prior to fracturing from pyritic decay.

A) Side of ovule, with pointed apex and flattened base, showing longitudinal ribs which merge towards the apex; B) Side view rotated 90 degrees side from A, showing 'bored' hole (arrow), and bilateral symmetry of the ribs and base; C) Basal view showing 12 ribs and the attachment scar; D) Oblique apex view showing the ribs tapering to a point, 'bored' hole indicated by arrow. Scale bar $=10 \mathrm{~mm}$. 

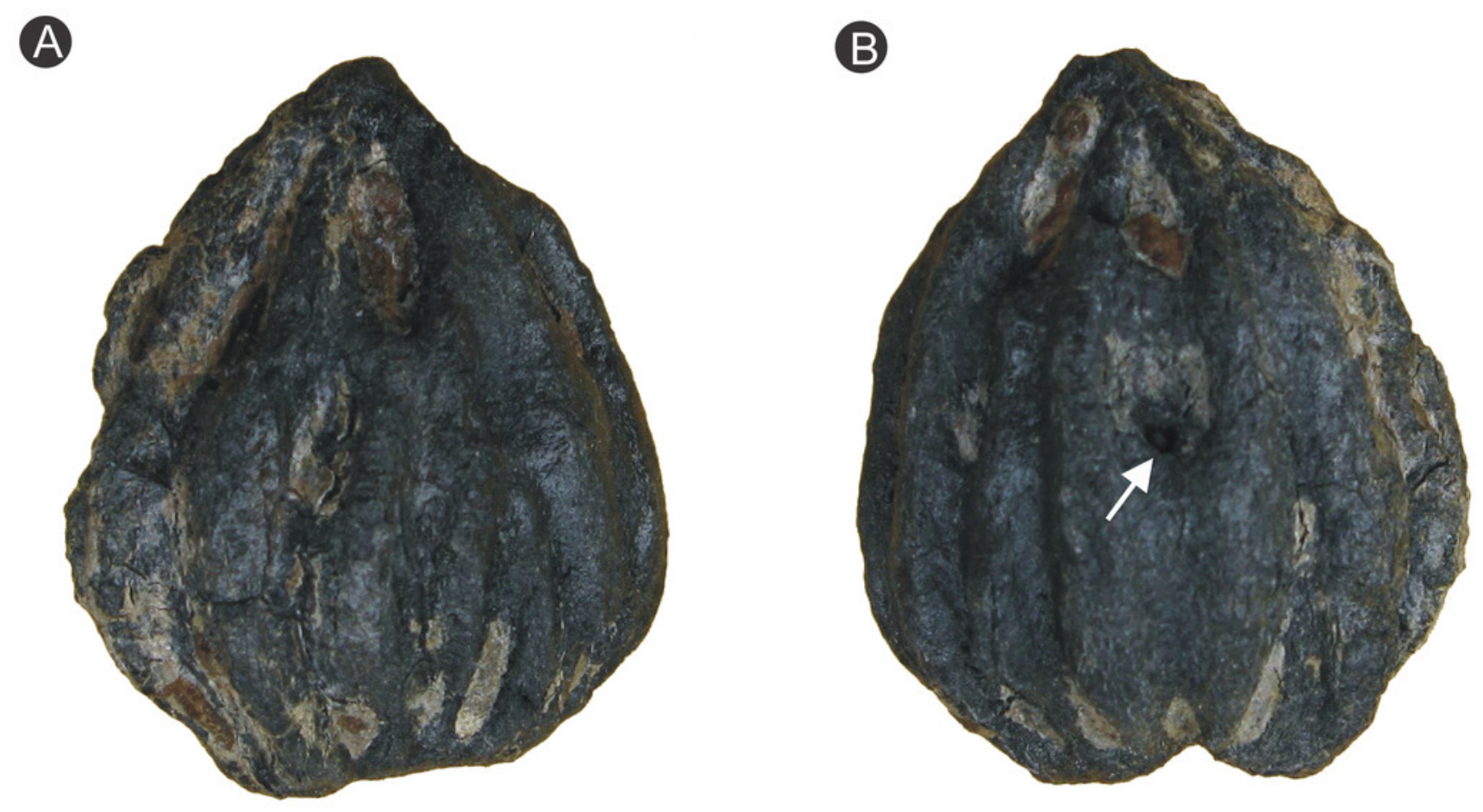
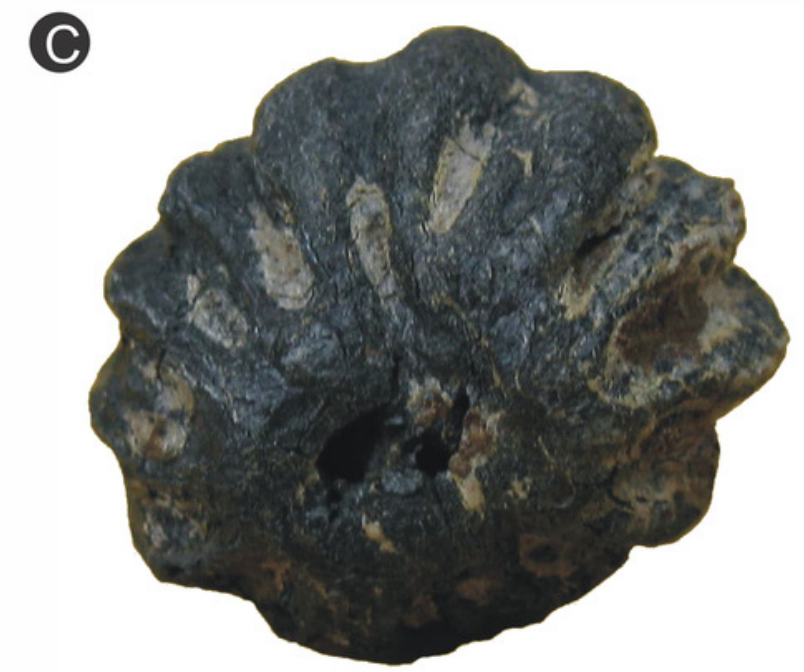

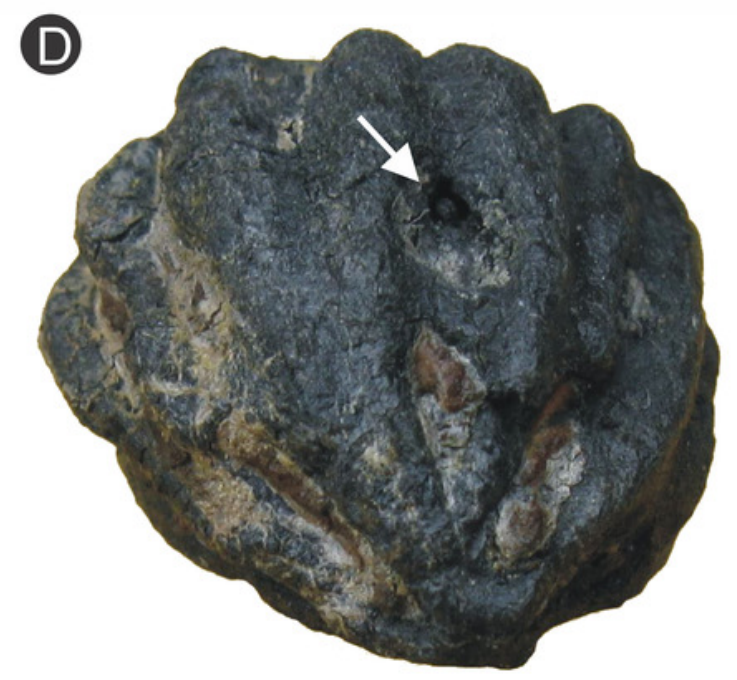




\section{Figure 4}

Photographs of specimen BU 5266 prior to serial wafering and peeling.

A) Side view of ovule showing decayed outer surface with eroded ribs; B) View of heavily decayed apex showing the rounded 12 ribbed nature of the ovule; C) Oblique side view showing ribbed outer surface, with zones of decay exposing inner integument, red staining on the base shows attachment scar; D) Basal view, note the four relatively intact ribs seen towards the image top, and the attachment scar denoted by the red staining. Scale bar $=10$ $\mathrm{mm}$. 

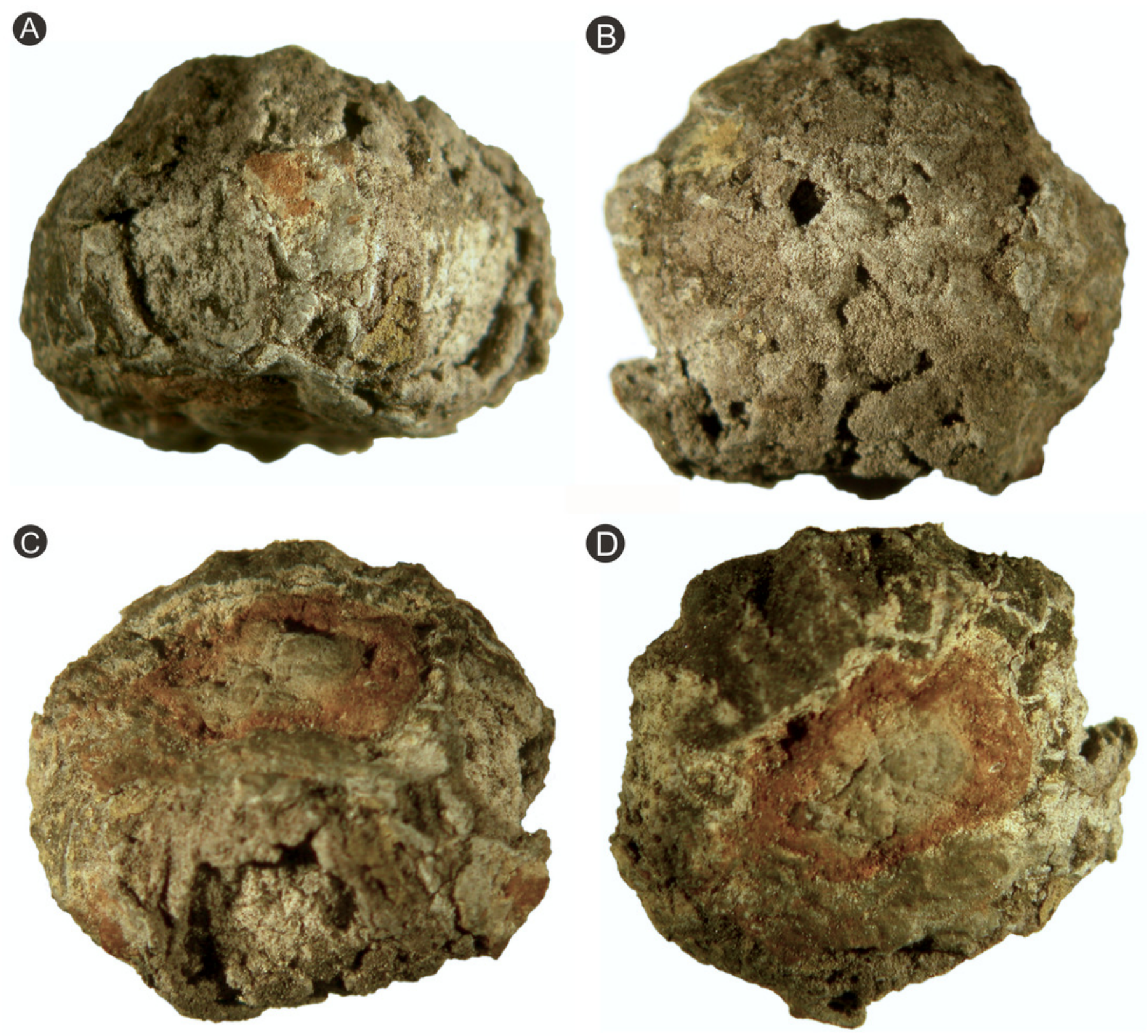
Figure 5

Diagram showing position of cuts, wafers and peels taken from specimen BU 5266.

Red lines = saw cuts; $p=$ peel; $w=$ wafer.

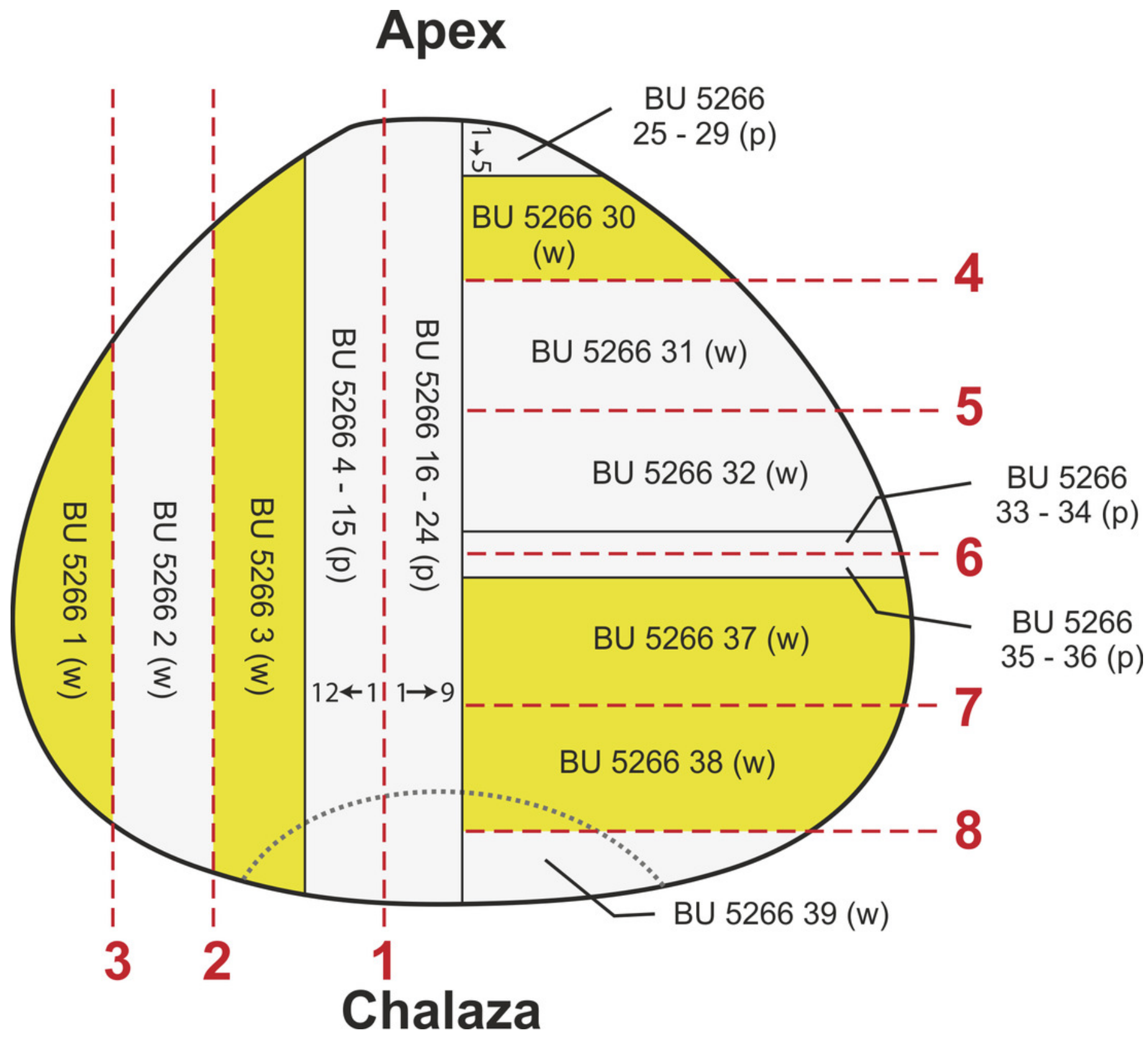




\section{Figure 6}

Virtual $25 \mu \mathrm{m}$ thin-sections showing gross morphology and anatomy of BU 5265.1 created from the Drishti volume rendered three-dimensional model.

Each figure shows (A, D) full SRXMT data in grayscale with enhanced brightness and contrast; $(B, E)$ false-colour image showing only the high density pyritic material; and $(C, F)$ the medium density organic and carbonate-rich materials. A-C) Longitudinal section through ovule. Showing at the apex a nucellar beak $(\mathrm{Nb})$ that protrudes from the top of the nucellar membrane $(\mathrm{N})$ within a defined micropyle $(\mathrm{Mi})$ region. Several major layers of the integument $\left(\right.$ Int $^{\circ}=$ outer; $\operatorname{lnt}^{m}=$ middle) are seen; D-F) Cross-section across ovule, approx. 1/4 distance from base to apex, line of section as marked on A-C. All scale bars $=1 \mathrm{~mm}$.

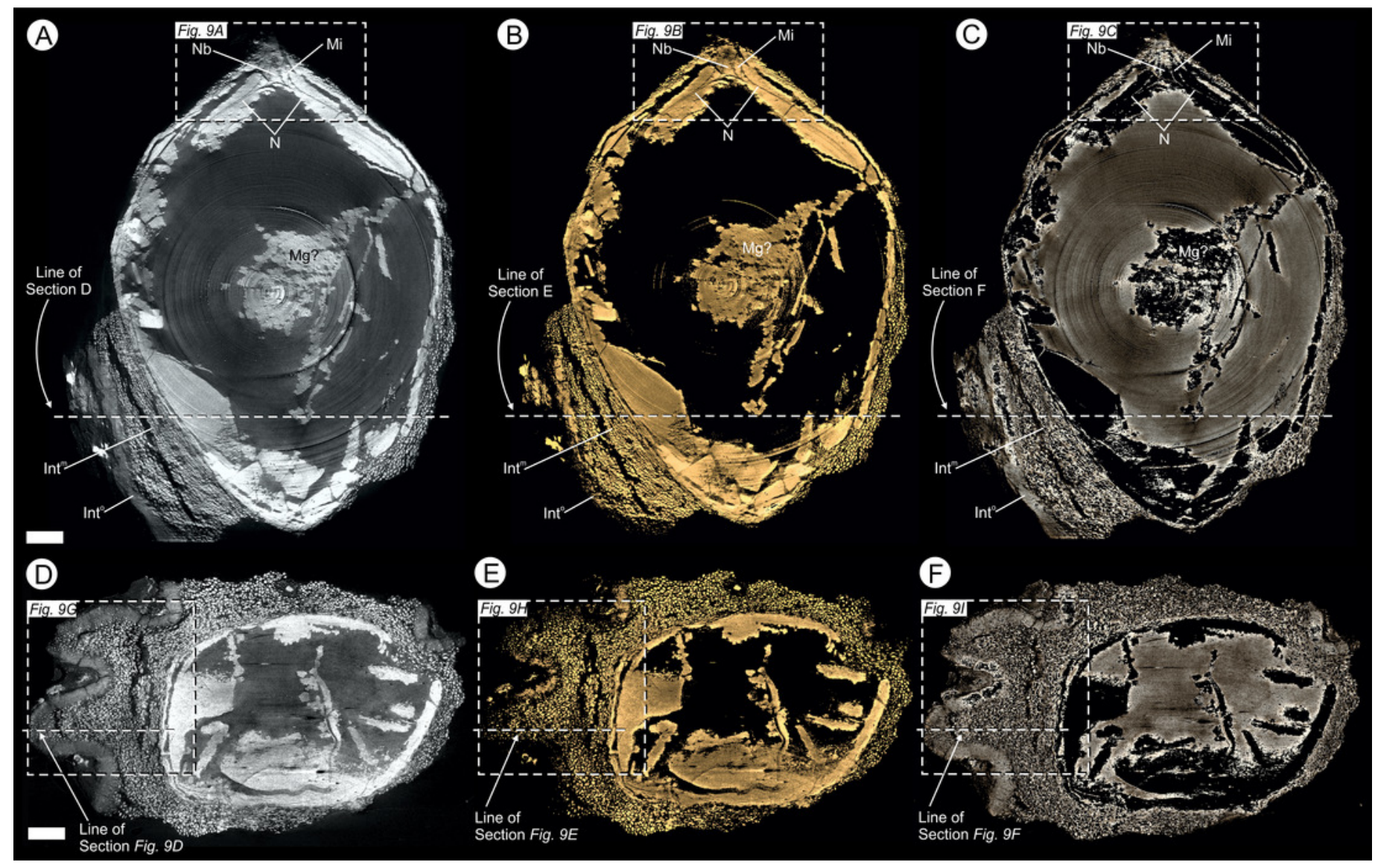




\section{Figure 7}

Gross morphology and internal feature distribution of BU 5266 viewed as wafers and virtual thick-sections.

Wafers A \& C viewed in reflective light photographed using a Zeiss Tessovar, and virtual thick-sections B \& C created from the SRXMT data in the Drishti volume rendered. A, B) cross-sectional wafer near ovule base with its three identified layers (Int ${ }^{0}=$ outer; $\operatorname{lnt}^{m}=$ middle; Int $\mathrm{t}^{\mathrm{I}}$ inner), nucellus (N), and megagametophyte (Mg); B) longitudinal wafer near ovule centre with its three identified layers $\left(I n t^{0}=\right.$ outer; $I n t^{m}=$ middle; Int ${ }^{i}=$ inner), nucellus $(\mathrm{N})$, megaspore membrane $(\mathrm{Mm})$, and megagametophyte $(\mathrm{Mg})$. Slides: $A, B=B U 5266.37$ BH.2.13.TS; C, D = BU 5266.3. All scale bars $=2 \mathrm{~mm}$.
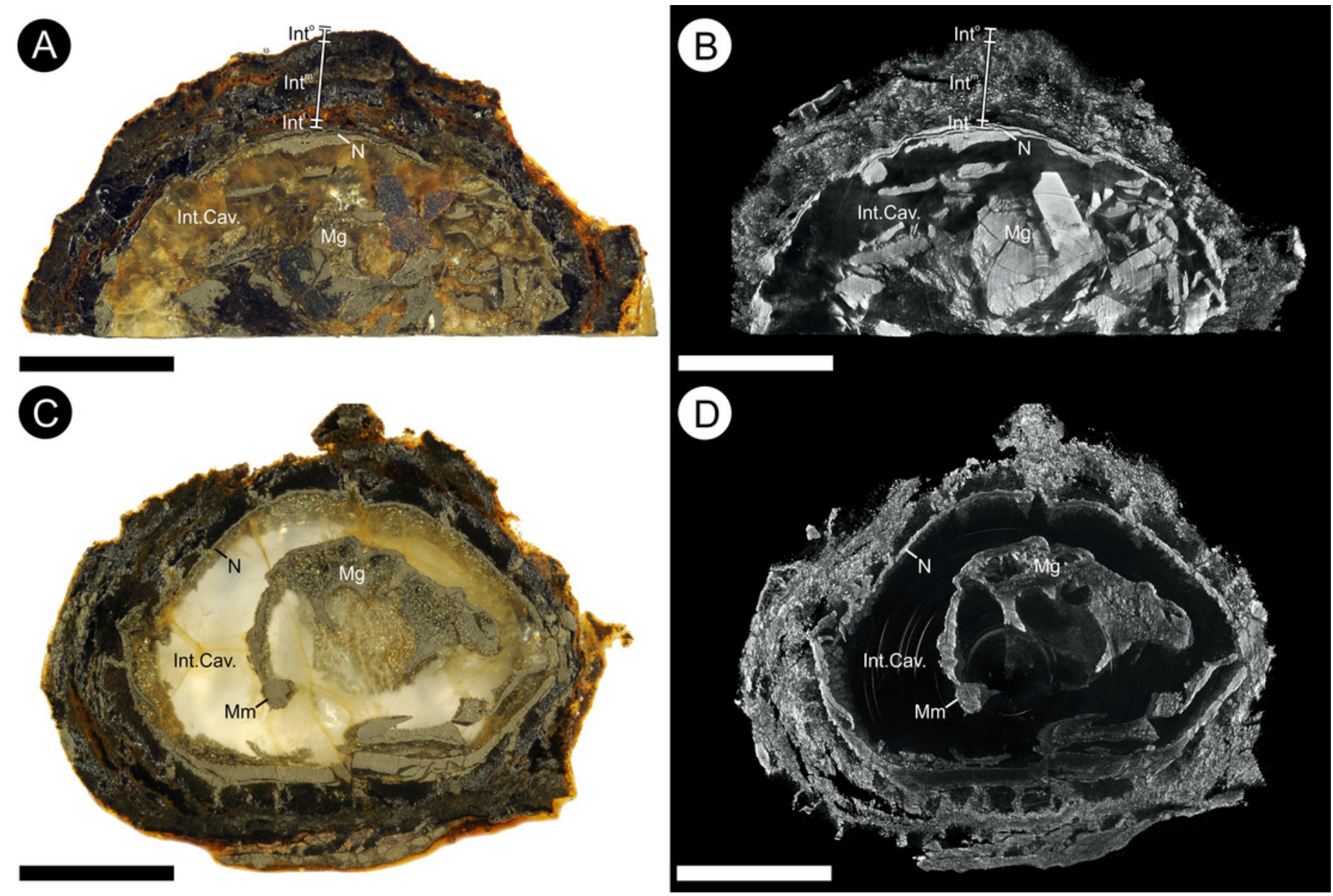


\section{Figure 8}

Three-dimensional isosurface-based false-coloured reconstruction model, BU 5265.1.
(A, B) and BU 5265.2 (C-D), showing gross morphology of the ovule. A) Longitudinal view showing ovule with partly remaining integument. The ribbed outer integument $\left(\operatorname{lnt}^{\circ}\right) \mathrm{can}$ be seen, with furrows containing Oxford Clay $(\mathrm{Cl})$, overlying the middle and inner integumentary layers $\left(\operatorname{Int}^{\mathrm{M}+1}\right)$. The cavity formed by the integument is digitally filled (Int. Cav.). Note the micropyle protruding from the apex (Mi); B) Basal view showing the heavily ribbed nature of the integument with attached Oxford Clay; C) Longitudinal view of a basal integument section showing the ribs terminating at towards the attachment scar; D) Longitudinal view 90 degrees from $C$ showing the flatten nature of the base and multi-layered construction of the integument; E) View of the integument section from the apex showing the middle and inner integument packing the central portions of the ribs. Scale bar $=10 \mathrm{~mm}$. Animations of these reconstructions can be seen in Videos S1 and S2. 


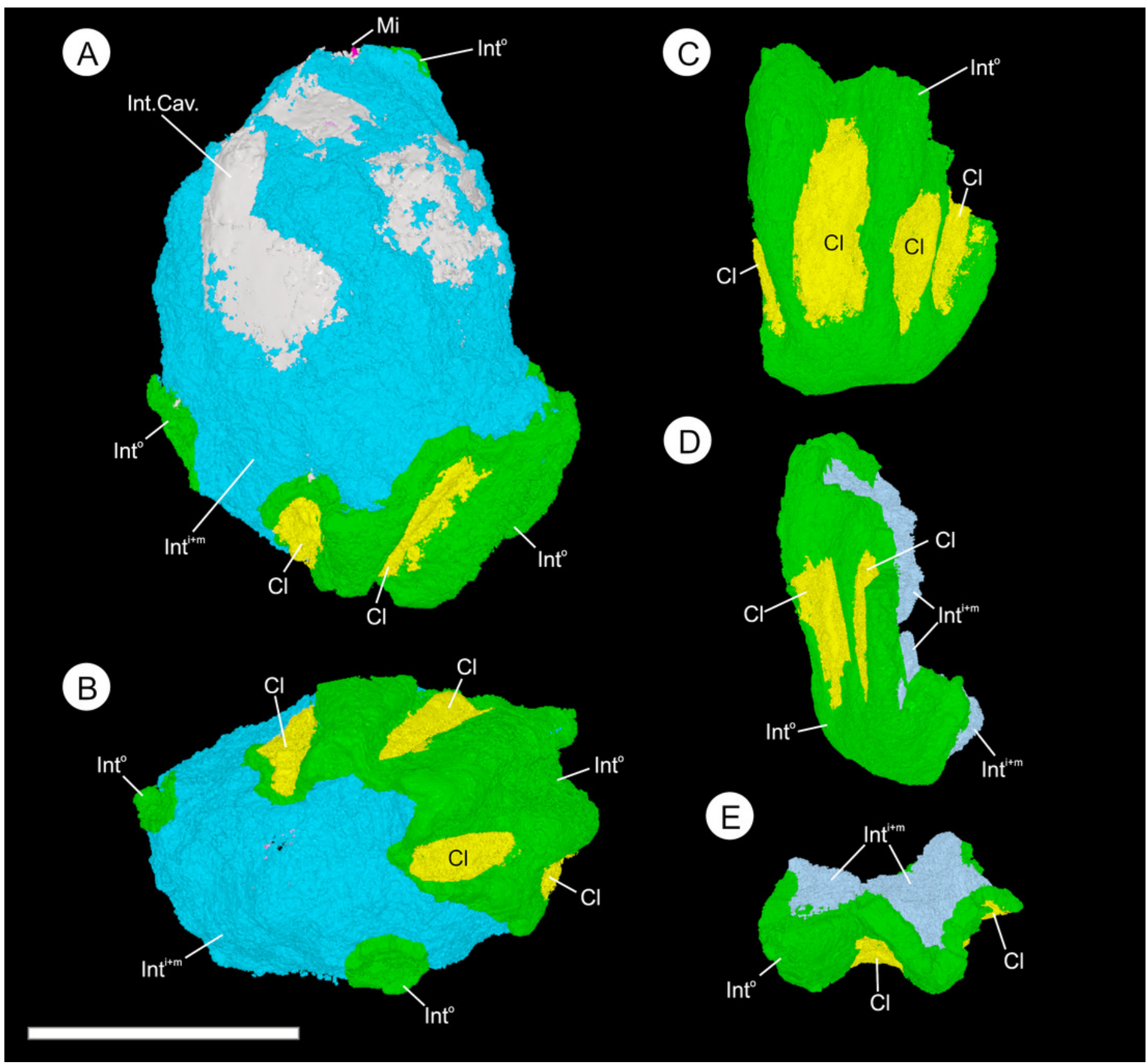




\section{Figure 9}

Virtual $25 \mu \mathrm{m}$ thin-sections showing gross morphology and anatomy of BU 5265.1 created from the Drishti volume rendered three-dimensional model.

A, D, G) full SRMT data in grayscale with enhanced brightness and contrast; $B, E, H$ ) falsecolour image showing only the high density pyritic material; and C, F, I) the medium density organic and carbonate rich materials. A, B, C) Enlarged longitudinal view of the apex seen in Fig. $6 \mathrm{~A}-\mathrm{C}$. Showing a nucellar beak $(\mathrm{Nb})$ that protrudes from the top of a possible small pollen chamber ( $\mathrm{Pc}$ ), the nucellar membrane ( $\mathrm{N})$, and the micropyle (Mi) region; $\mathrm{C}-\mathrm{F}$ ) Longitudinal section of integument, through the maximum width of a rib, line of section as marked on Fig. $6 D-F$. Showing the three identified layers of the integument $\left(\operatorname{Int}^{\circ}=\right.$ outer; $\operatorname{Int}^{\mathrm{m}}=$ middle; $\operatorname{Int} \mathrm{t}^{\mathrm{i}}$ $=$ inner), $\mathrm{F}$ also shows the location of the nucellus (N); G-I) Enlarged cross-sectional view of integument, as marked on Fig. 6D-F. Showing two ribs, with Oxford Clay infill in the rib furrow, and the integument with its three identified layers $\left(\operatorname{Int}^{0}=\right.$ outer; $\operatorname{Int}^{\mathrm{m}}=$ middle; $\operatorname{Int} \mathrm{t}^{\mathrm{i}}=$ inner). All scale bars $=1 \mathrm{~mm}$. 


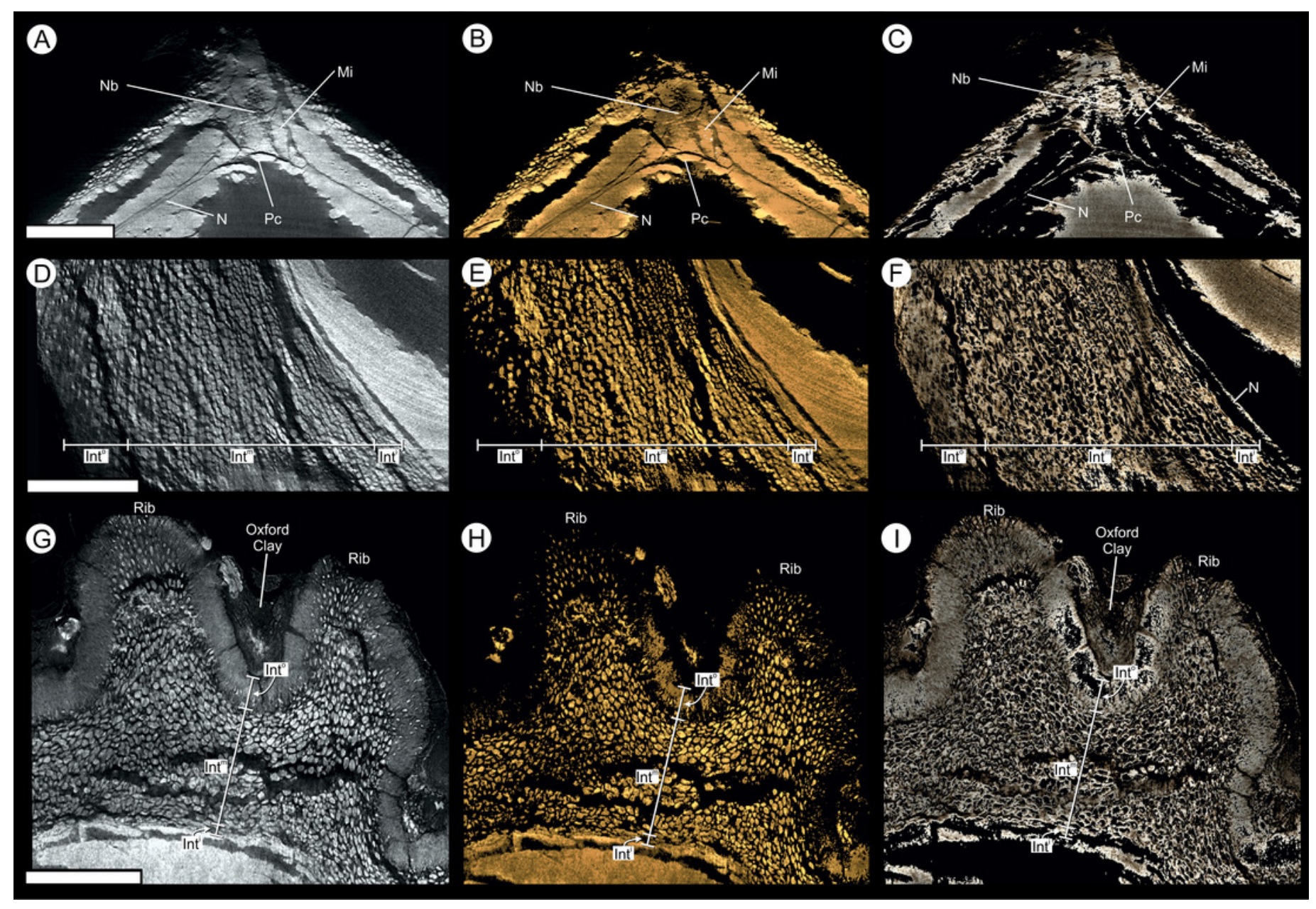




\section{Figure 10}

Physical wafer and peel sections of BU 5266 showing state of preservation and anatomy.

Wafers (reflective light) and peels (transmitted) light where photographed using a Zeiss Tessovar. A) Longitudinal wafer showing the extensive pyrite and pyritic decay of the integument with patches of preserved middle integument (Int) and small portions of nucellus (N). Slide BU 5266.3. B) Longitudinal peel showing integument with its thin inner layers (Int') and middle layer $\left(\operatorname{lnt}^{\mathrm{m}}\right)$. The external surface of the integument is degraded (left of image). Slide BU 5266.12. C) Enlarged view from A showing the preserved middle integument cells. Slide BU 5266.3 D) Longitudinal wafer showing micropyle (Mi) at the middle top of the ovule, the thin nucellus $(\mathrm{N})$ closely following integument, and the megaspore membrane $(\mathrm{Mm})$ and megagametophyte (Mg) within the integumentary cavity. Slide BU 5266.3. E, F) High magnification of wafer showing the construction of the nucellus (N). Slide BU 5266.2. G) High magnification of preserved cells from within the megaspore membrane interpreted as megagametophyte tissue $(\mathrm{Mg})$. Slide BU 5266.37. Scale bars: $A, D=1 \mathrm{~mm}, E=0.5 \mathrm{~mm}$, all others $0.25 \mathrm{~mm}$. 

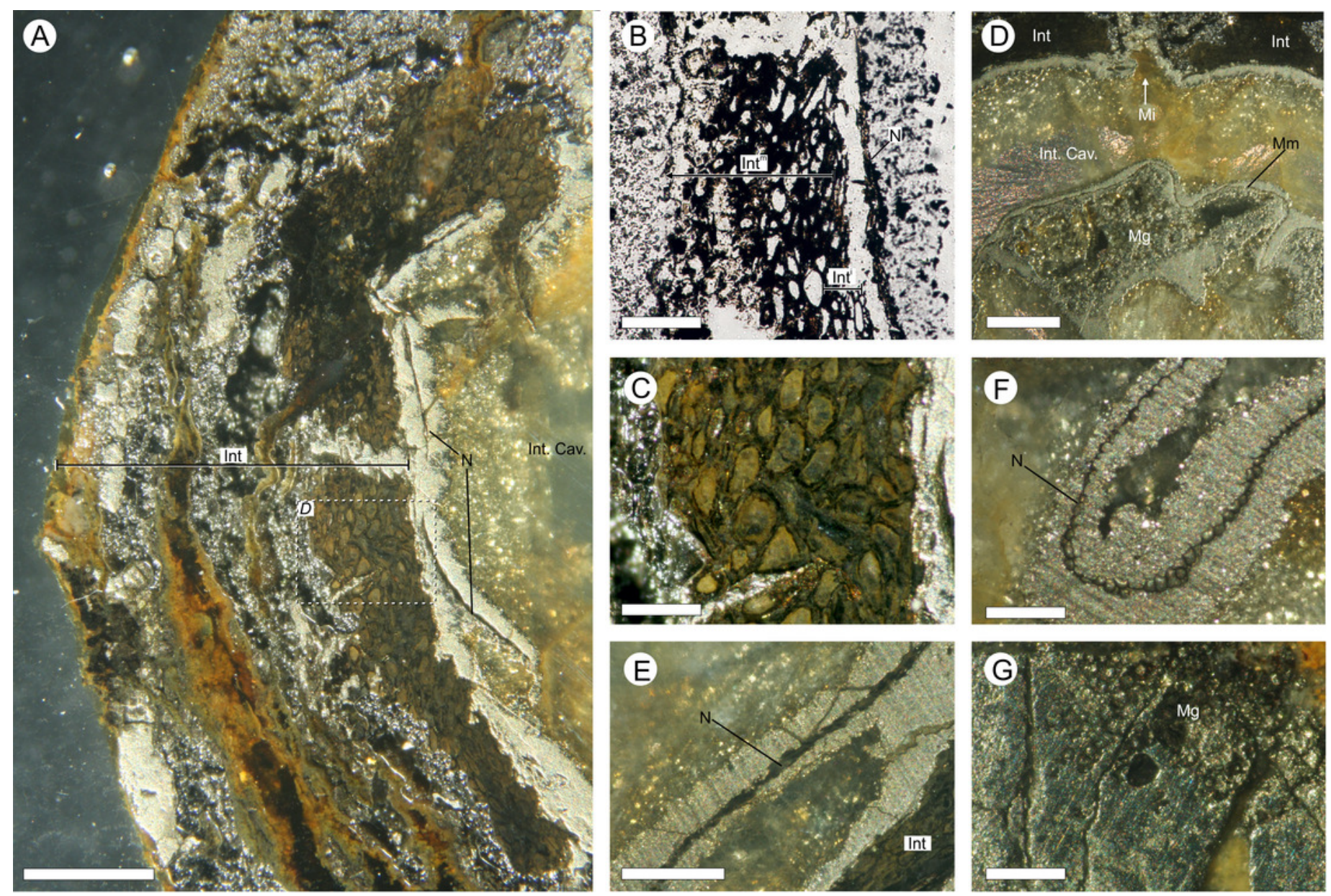


\section{Figure 11}

Three-dimensional isosurface-based false-coloured reconstruction model of BU 5265.1 showing a digitally filled integumentary cavity cast.

A) Longitudinal view looking along the central apex ridge; B) apex view of the ridge with the micropyle protruding (Mi); C) longitudinal view showing the apex ridge with central micropyle in profile. Scale bars $=5 \mathrm{~mm}$.
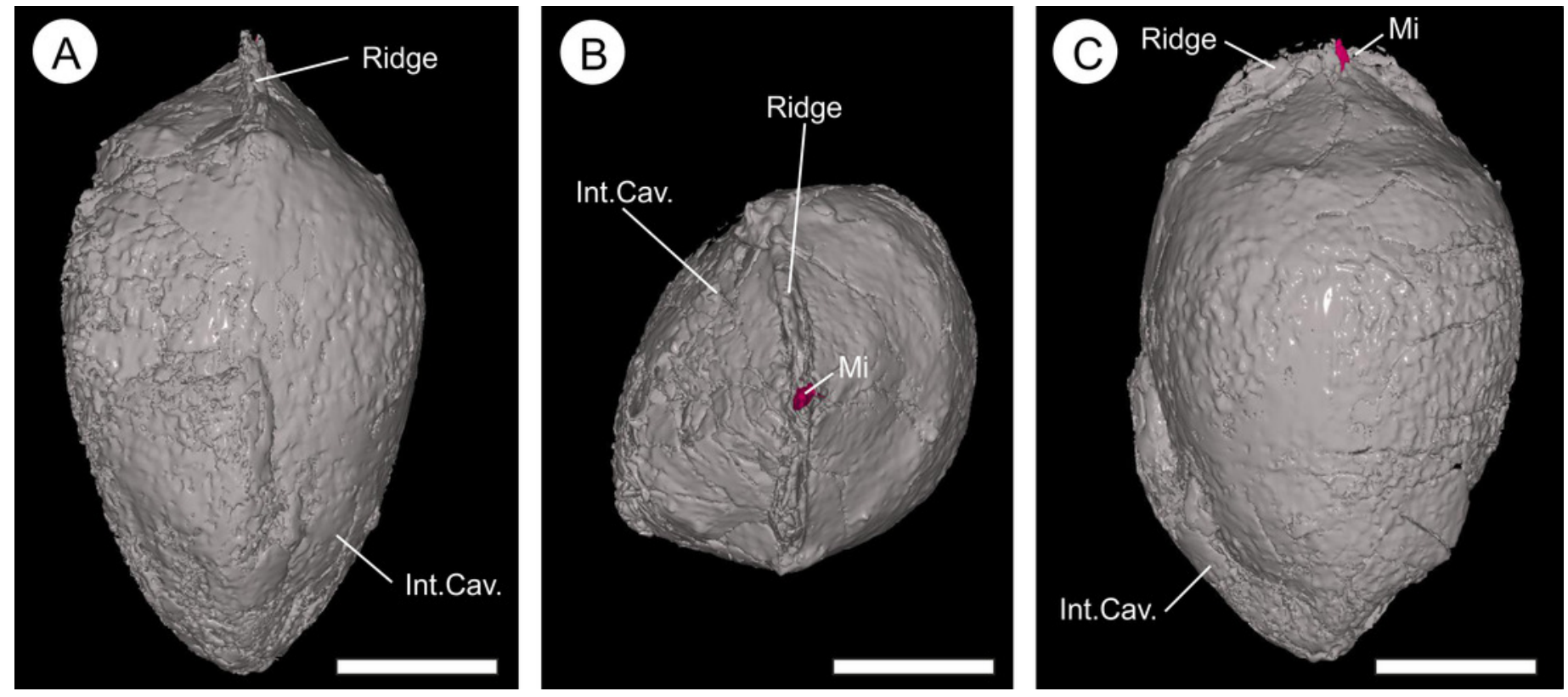


\section{Figure 12}

Three-dimensional isosurface-based false-coloured reconstruction model of BU 5265.1 showing internal ovule morphology.

A) Ovule, with Oxford Clay and digitally filled integumentary cavity removed, showing the multi-layered integument ( $\left(\operatorname{lnt}^{0}\right.$ and $\left.\operatorname{Int}^{\mathrm{M}+1}\right)$ surrounding a large nucellus $(\mathrm{N})$ with micropyle channel at apex (digitally infilled; Mi); B) Longitudinal section through the middle of $\mathrm{A}$. The nucellus, which has deteriorated towards the back of the view, possesses a small nucellar beak at is apex ( $\mathrm{Nb}$ ), that protrudes into the micropyle channel (digitally infilled; $\mathrm{Mi}$ ); C) Nucellus ( $\mathrm{N}$ ) and digitally infilled micropyle (Mi), shown without surrounding integument; D) Enlarged apex view of $\mathrm{C}$, with micropyle channel (Mi) shown as semi-transparent, and nucellus beak $(\mathrm{Nb})$ within. Dashed line indicates the boundary between the digitally infilled micropyle and the nucellar beak; E) Longitudinal section through the apex of D. Showing the nucellus $(\mathrm{N})$, with small pollen chamber (Pc) that resided below the nucellar beak ( $\mathrm{Nb})$. The digitally infilled micropyle (Mi) is shown.; F) Cross-section through $E$, showing relationship between nucellus $(\mathrm{N})$, the nucellar beak $(\mathrm{Nb})$, and the micropyle (Mi). Scale bars: $A, B=5$ $\mathrm{mm} ; \mathrm{C}=1 \mathrm{~cm} ; \mathrm{D}-\mathrm{F}=1 \mathrm{~mm}$. 

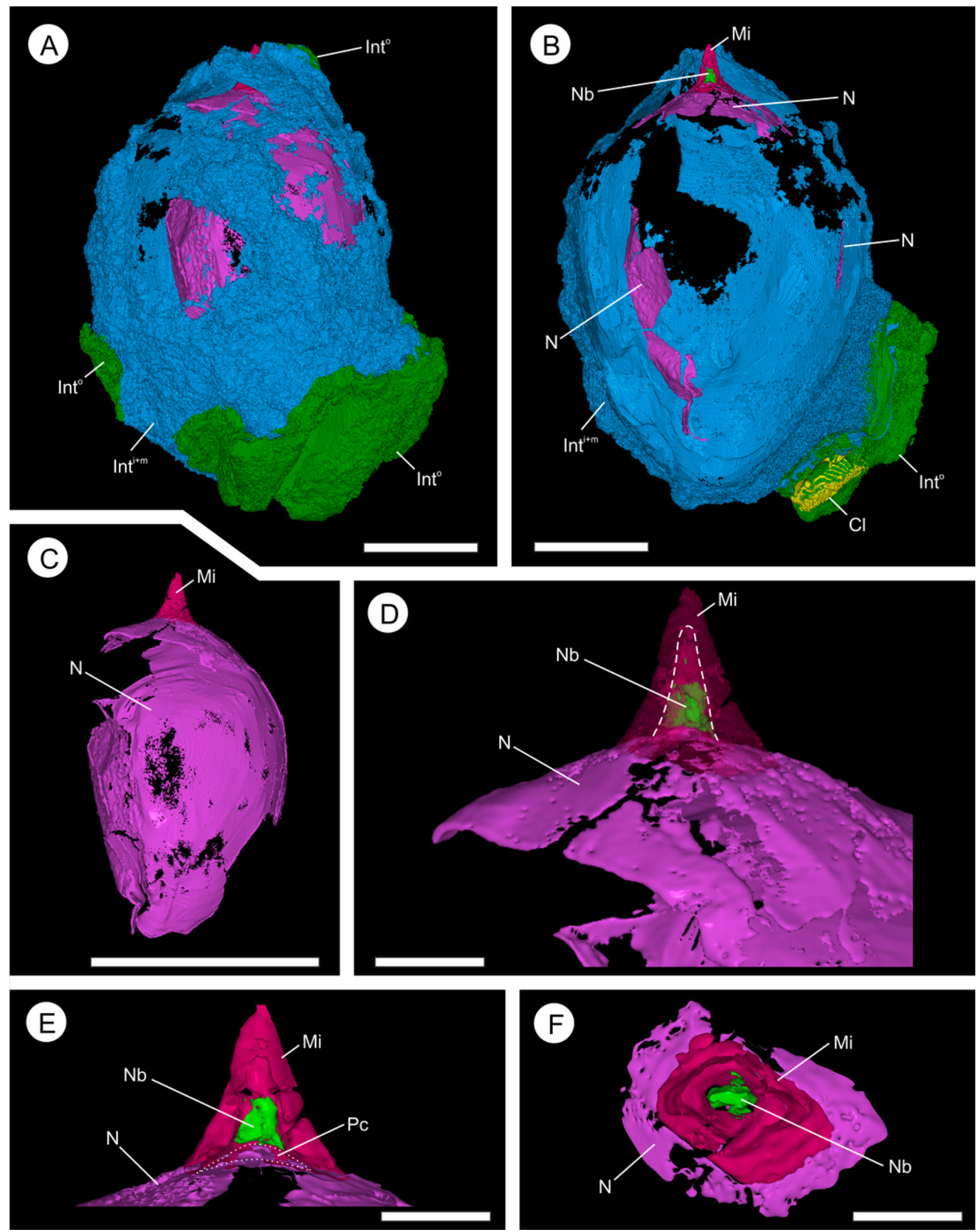


\section{Figure 13}

Original pen and ink drawings of Cycadeospermum ovules from Saporta $(1875 ; 1891)$.

A) C. schlumbergeri from Plate CXVII Fig. 11 of Saporta (1875) showing ovule looking down on apex with ribbed integument and lateral opening (arrow); B) C. schlumbergeri from Plate CXVII Fig. 12 of Saporta (1875) showing longitudinal view of ovule with ribbed integument, pointed apex and flattened base; C) C. berlieri from Plate CCXCVIII Fig. 3 of Saporta (1891) showing longitudinal view of ovule with ribbed integument; D) Smaller specimen of $C$. berlieri from Plate CCXCVIII Fig. 4 of Saporta (1891) showing longitudinal view of ovule with ribbed integument; E) C. choffati from Plate CCXCVIII Fig. 5 of Saporta (1891) showing longitudinal view of ovule with ribbed integument, with attachment point at base. Scale bar $=c a .1 \mathrm{~cm}$ (based on information given by Saporta in text).
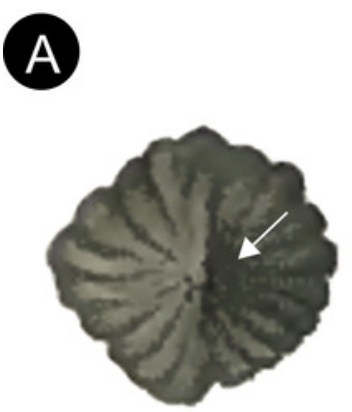

\section{B}

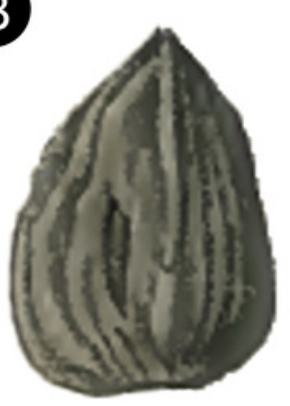

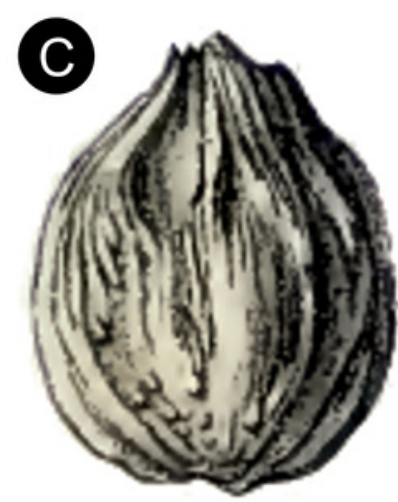

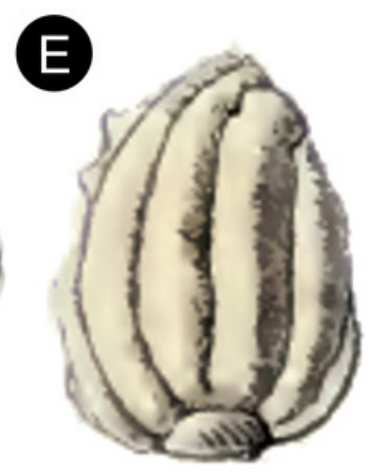




\section{Figure 14}

Fossilization phase diagram.

Illustrating the qualitative changes at varying depths/zones $(A)$ in dissolved iron and sulphide

(B) and how these changes affect the saturation state between iron and carbonate during microbial diagenesis (C), as well as showing the related different styles of fossilization (D). E) An SRXMT longitudinal section of BU 5265.1 showing the two phases of mineralization. See Figure S1 A-D for more SRXMT section images. Phase data based on Raiswell (1997).

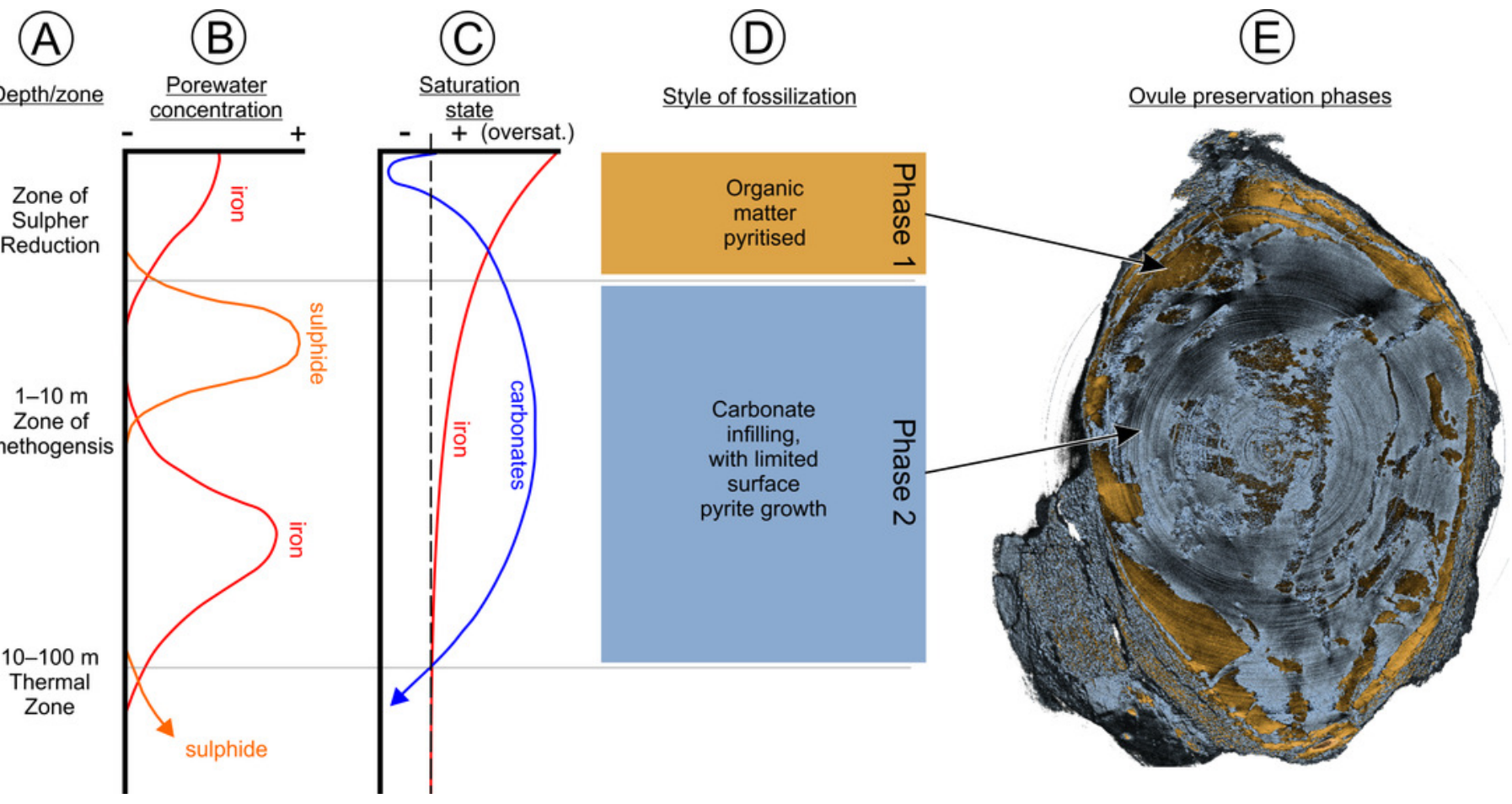

